\title{
Interactive effect of 24-epibrassinolide and silicon alleviates cadmium stress via the modulation of antioxidant defense and glyoxalase systems and macronutrient content in Pisum sativum L. seedlings
}

\author{
Sumira Jan ${ }^{1}$, Mohammed Nasser Alyemeni ${ }^{2}$, Leonard Wijaya², Pravej Alam³ ${ }^{3}$ Kadambot H. Siddique ${ }^{4}$
} and Parvaiz Ahmad ${ }^{2,5^{*}}$ (i)

\begin{abstract}
Background: This study assessed the effects of 24-epibrassinolide (EBL, $\left.10^{-7} \mathrm{M}\right)$ and silicon (2 mM) on the alleviation of cadmium ( $\left.\mathrm{Cd}, 150 \mathrm{mg} \mathrm{L}^{-1}\right)$ toxicity in Pisum sativum L. seedlings via the modulation of growth, antioxidant defense, glyoxalase system, and nutrient uptake.

Results: Shoot and root lengths declined by $46.43 \%$ and $52.78 \%$, respectively, following $\mathrm{Cd}$ stress. Shoot and root dry weights also declined with $\mathrm{Cd}$ toxicity. Biochemical and physiological aspects exhibit significant decline including total chlorophyll (33.09\%), carotenoid (51.51\%), photosynthetic efficiency (32.60\%), photochemical quenching (19.04\%), leaf relative water content (40.18\%), and gas exchange parameters (80.65\%). However, EBL or Si supplementation alone or in combination modulates the previously mentioned parameters. Cadmium stress increased proline and glycine betaine (GB) contents by 4.37 and 2.41 -fold, respectively. Exposure of plants to $\mathrm{Cd}$ stress increased the accumulation of $\mathrm{H}_{2} \mathrm{O}_{2}$, malondialdehyde content, electrolyte leakage, and methylglyoxal, which declined significantly with EBL and Si supplementation, both individually and in combination. Similarly, Cd stress adversely affected enzymatic and non-enzymatic antioxidants, but EBL and/or Si supplementation maintained antioxidant levels. Glyoxalase I (Glyl) accumulated after $\mathrm{Cd}$ stress and increased further with the application of EBL and Si. However, Glyll content declined after Cd stress but increased with supplementation of EBL and Si. Cadmium accumulation occurred in the following order: roots > shoots>leaves. Supplementation with EBL and Si, individually and in combination reduced $\mathrm{Cd}$ accumulation and enhanced the uptake of macronutrients and micronutrients in shoots and roots, which declined with Cd toxicity.
\end{abstract}

Conclusion: The application of 24-EBL and Si, individually and in combination, alleviated the adverse effects of $\mathrm{Cd}$ by improving growth, biochemical parameters, nutrient uptake, osmolyte accumulation, and the anti-oxidative defense and glyoxalase systems in Pisum sativum seedlings.

Keywords: Pisum sativum, Cadmium stress, 24-Epibrassinolide, Silicon, Lipid peroxidation, Antioxidants, Glyoxalase system

\footnotetext{
* Correspondence: parvaizbot@yahoo.com

${ }^{2}$ Department of Botany and Microbiology, Faculty of Science, King Saud University, Riyadh 11451, Saudi Arabia

${ }^{5}$ Department of Botany, S.P. College, Srinagar, Jammu, Kashmir 190001, India

Full list of author information is available at the end of the article
}

(c) The Author(s). 2018 Open Access This article is distributed under the terms of the Creative Commons Attribution 4.0 International License (http://creativecommons.org/licenses/by/4.0/), which permits unrestricted use, distribution, and reproduction in any medium, provided you give appropriate credit to the original author(s) and the source, provide a link to the Creative Commons license, and indicate if changes were made. The Creative Commons Public Domain Dedication waiver (http://creativecommons.org/publicdomain/zero/1.0/) applies to the data made available in this article, unless otherwise stated. 


\section{Background}

Heavy metal contamination is a serious threat caused by anthropogenic activities such as mining, wastewater and sewage sludge utilization for irrigationpurposes, phosphate fertilizer application, and increased vehicular and industrial emissions [1-3]. Heavy metal contamination causes morphological, physiological, biochemical, and ultra-structural alterations in plants [4]. Cadmium (Cd) is among the comparatively mobile heavy metals in soil and is highly toxic to both plants and animals $[5,6]$. Cadmium accumulates progressively in humans via the food chain [6-9], leading to human disorders such as Itai-Itai disease, cancer, neurotoxicity, and nephrotoxicity [5]. Vegetables and cereals are the primary food sources for the world's population. Accumulation of $\mathrm{Cd}$ in vegetables is noted when fields are irrigated with wastewater and sewage sludge in peri-urban areas [10]. $\mathrm{Cd}$ toxicity reduces plant growth, biomass, photosynthesis, yield, and quality $[11,12]$. Further, it impairs mineral nutrition in plants $[13,14]$. Several studies have shown that $\mathrm{Cd}$ toxicity alters nitrogen metabolism, reduces photosynthetic efficiency caused by impaired chlorophyll synthesis, and reduces carbon fixation [8, 9]. Increased $\mathrm{Cd}$ accumulation hampers root morphology, resulting in stunted growth [15], and thus causes oxidative stress in vegetables via the generation of reactive oxygen species (ROS), which damage the antioxidant enzyme system $[1,16]$. To tolerate Cd stress, plants have developed advanced tolerance strategies, including osmoprotectant synthesis and antioxidant defense and glyoxalase systems [1, 8, 16-20]. Enzymatic and non-enzymatic antioxidants related to the ascorbate-glutathione cycle have a crucial role in stress tolerance mechanisms in plants [2, 17, 21]. The enzymatic antioxidants include superoxide dismutase (SOD), catalase (CAT), ascorbate peroxidase (APX), glutathione reductase (GR), monodehydroascorbate reductase (MDHAR), dehydroascorbate reductase (DHAR), and glutathione-S-transferase (GST); non-enzymatic antioxidants include ascorbic acid (AsA) and glutathione (GSH). In addition to the antioxidant defense system, the glyoxalase system [glyoxalase I (Gly I) and glyoxalase II (Gly II)] facilitates the detoxification of methylglyoxal (MG) [21, 22]. However, Cd toxicity exhibits diverse specificity within vegetable cultivars and genotypes $[23,24]$. Leafy vegetables accumulate more $\mathrm{Cd}$ than vegetable roots and tubers [25].

Numerous strategies have been proposed to combat $\mathrm{Cd}$ toxicity encompassing the exogenous application of organic and inorganic amendment such as plant growth regulators as well as mineral amendments like silicon and selenium [1, 2, 10, 16-18, 26-28]. Among the phytohormones significance of brassinosteroids (BRs) in alleviation of stress is more expansively reported [2, 29-32]. Mineral amendment in plant media has also been reported of functional significance to alleviate heavy metal toxicity. Silicon ( $\mathrm{Si}$ ) is the one among such minerals that is well documented for the amelioration of various biotic and abiotic stresses [33, 34]. Accumulation of Si under the leaf surface enhances both biotic and abiotic stress tolerance by reducing the transpiration rate and thus restoring water utilization competence [35]. Si bio-fortification is also associated with an improved oxidative defense system and enhanced membrane integrity in plants subjected to various abiotic and biotic stresses [8, 34].

Brassinosteroids are a category of steroidal phytohormones that are present in plant parts, including roots [24]; they modulate an extensive range of physiological responses, including cellular and metabolic functions [8]. Moreover, BRs exhibit diverse ameliorative effects against varied stresses such as thermal stress [36], oxidative damage [37], and heavy metal toxicity [38, 39]. Studies have shown that exogenous BRs alleviated Cd stress in tomato [40], bean [41], tobacco [42], and peanut [43]. The possible relevance of BRs in agriculture is determined primarily by their competence to augment crop yield and modulate stress-induced damage. However, whether Si and 24-epibrassinolide (EBL) can ameliorate $\mathrm{Cd}$-induced physiological and metabolic alterations is still unraveled.

Pea is an important legume crop that is widely cultivated globally for its nutritive value. The indiscriminate use of fertilizers has caused an enormous flow of $\mathrm{Cd}$ into pea fields, which has become detrimental to the quality of pea for human and livestock consumption. Numerous health risks are associated with Cd uptake by plants [44]. Keeping in view the alleviation potential of EBL and Si against $\mathrm{Cd}$ toxicity, we hypothesize that individual and combined treatment of $\mathrm{Si}$ and EBL can modulate biochemical status and anti-oxidant defense system in pea seedlings. Therefore, this study evaluated the effect of EBL and $\mathrm{Si}$, individually and in combination, on the growth, physiology, nutrient uptake, and antioxidant defense and glyoxalase systems in pea plants grown under $\mathrm{Cd}$ stress.

\section{Methods}

Seeds of pea (Pisum sativum L.) were sterilized using 5\% $\mathrm{NaOCl}$ for $5 \mathrm{~min}$ and washed with double-distilled water. Seeds were pretreated with EBL $\left(10^{-7} \mathrm{M}\right)$ for $8 \mathrm{~h}$. The seeds were sown in pots containing sand, perlite, and peat in a 1:1:1 ratio. After germination, seedlings were thinned to one per pot. From sowing to 10 days of seedling growth, pots were supplemented with $200 \mathrm{~mL}$ full-strength Hoagland solution every alternate day [45]. After 10 days, seedlings were treated with $\mathrm{Cd}$ $\left(\mathrm{CdSO}_{4} \cdot 8 \mathrm{H}_{2} \mathrm{O} ; 150 \mathrm{mg} \mathrm{L}^{-1}\right)$ in a modified Hoagland solution. Silicon (2 $\mathrm{mM}, 10 \mathrm{~mL})$ was supplemented in the form of $\mathrm{Na}_{2} \mathrm{SiO}_{3}$ with Hoagland solution. Silicon was supplied every alternate day to plants after one week of $\mathrm{NaCl}$ treatment up to 40 days. Pots were maintained in 
a growth chamber set at $26 \pm 2{ }^{\circ} \mathrm{C} / 15 \pm 2{ }^{\circ} \mathrm{C}$ day/night temperatures, $70-75 \%$ relative humidity, and an average $18 \mathrm{~h}$ light dark photoperiod. After 40 days of treatment, the plants were carefully uprooted and analyzed for different parameters. The biochemical and antioxidant activities were estimated using secondary leaves.

\section{Determination of growth parameters}

Shoot and root lengths were measuredwith a ruler. Shoot and root fresh weights (FW) were determined immediately after harvesting, and dry weights (DW) were determined after oven drying at $70^{\circ} \mathrm{C}$ for $72 \mathrm{~h}$.

\section{Determination of pigments}

Chlorophyll content in leaves was extracted using dimethyl sulphoxide (DMSO), and absorbance was determined spectrophotometrically at 480,510, 645, and 663 nm (Beckman 640 D, USA) against DMSO [46]. The total carotenoid content was determined using $80 \%$ acetone extracts of the plant material, according to the spectrophotometric method of Lichtenthaler and Wellburn [47].

\section{Chlorophyll fluorescence}

Chlorophyll fluorescence was measured using a portable pulse modulation fluorometer (PAM 2500; Waltz $\mathrm{GmbH}$, Effeltrich, Germany). Leaves from each plant were randomly selected from one replication per treatment and dark-adapted for approximately $10 \mathrm{~min}$ (based on the previous experiment),before measuring initial fluorescence (Fo), maximal fluorescence (Fm), actual photochemical efficiency of PSII ( $\Phi$ PSII), photochemical quenching (qP), and non-photochemical quenching (NPQ) at $1200 \mu \mathrm{mol} \mathrm{m}{ }^{-2} \mathrm{~s}^{-1}$ PAR. After the actinic light (AL) source was removedand $3 \mathrm{~s}$ of far-red light was applied, the minimal fluorescence of the light-adapted state (Fo') was obtained. Steady-state fluorescence (Fs) was determined under AL $(\lambda=665 \mathrm{~nm})$. The relative effective quantum yield of photochemical energy conversion at steady-state photosynthesis was calculated as yield $=\left(\mathrm{Fm}^{\prime}-\mathrm{Fs}\right) / \mathrm{Fm}^{\prime}$, where $\mathrm{Fs}$ and $\mathrm{Fm}^{\prime}$ are the fluorescence at steady-state photosynthesis and maximum fluorescence in the light, respectively. Next, qP, $\Phi$ PSII, and NPQ were calculated as $\left(\mathrm{Fm}^{\prime}-\mathrm{Fs}\right) /\left(\mathrm{Fm}^{\prime}-\mathrm{Fo}^{\prime}\right)$, $\left(\mathrm{Fm}^{\prime}-\mathrm{Fs}\right) / \mathrm{Fm}^{\prime}$, and $\left(\mathrm{Fm}-\mathrm{Fm}^{\prime}\right) / \mathrm{Fm}$, respectively [48].

\section{Determination of $\mathrm{H}_{2} \mathrm{O}_{2}$ content, lipid peroxidation, and electrolyte leakage}

Fresh leaf samples $(500 \mathrm{mg})$ were homogenized in $5 \mathrm{~mL}$ of trichloroacetic acid $(0.1 \%, \mathrm{w} / \mathrm{v})$, and the homogenate centrifuged at $12,000 \mathrm{~g}$ for $15 \mathrm{~min}$. Next, $0.5 \mathrm{~mL}$ supernatant was mixed with $0.5 \mathrm{~mL}$ of $10 \mathrm{mM}$ potassium phosphate buffer ( $\mathrm{pH} 7.0)$ and $1 \mathrm{~mL}$ of $1 \mathrm{M}$ potassium iodide. The optical density was recorded at $390 \mathrm{~nm}$ [49].
The method of Madhava Rao and Sresty [50] was used to measure lipid peroxidation (formation of malondialdehyde (MDA). Fresh leaf tissue $(500 \mathrm{mg}$ ) was homogenized in $2.5 \mathrm{~mL}$ of trichloroacetic acid $(0.1 \%)$, followed by centrifugation at 10,000gfor $10 \mathrm{~min}$. Next, a $1 \mathrm{~mL}$ aliquot was mixed with $4 \mathrm{~mL}$ of $20 \%$ trichloroacetic acid containing $0.5 \%$ of thiobarbituric acid, and heated at $95^{\circ} \mathrm{C}$ for 30 min. The mixture was cooledin anice bath and centrifuged again for $15 \mathrm{~min}$ at $10,000 \mathrm{~g}$. The absorbance was measured at $532 \mathrm{~nm}$, and corrections were performedfor unspecific turbidity by subtracting the absorbance at $600 \mathrm{~nm}$.

To estimate electrolyte leakage, 20 leaf discs were immersed in test tubes containing deionized water, and the electrical conductivity was measured (ECa). Subsequently, tubes were heated in a water bath for $25 \mathrm{~min}$ at $50^{\circ} \mathrm{C}$, and the electrical conductivity $(\mathrm{ECb})$ was measured. The tubes were heated again for $10 \mathrm{~min}$ at $100^{\circ} \mathrm{C}$, and the electrical conductivity (ECc) was measured [51]. Electrolyte leakage (EL) was calculated as follows:

$$
\text { Electrolyte leakage }(\%)=\frac{\mathrm{EC}_{\mathrm{b}}-\mathrm{EC}_{\mathrm{a}}}{\mathrm{EC}_{\mathrm{c}}} \times 100
$$

\section{Measurement of methylglyoxal level}

The method of Wild, et al. [52] was used to estimate methylglyoxal (MG). Fresh leaves $(500 \mathrm{mg}$ ) were crushed in perchloric acid (5\%) and subjected to centrifugation at $4^{\circ} \mathrm{C}$ for $10 \mathrm{~min}$ at $11,000 \mathrm{~g}$. The collected supernatant was mixed with charcoal to decolorize and then neutralized with saturated potassium carbonate solution. Sodium dihydrogen phosphate and $N$-acetyl-L-cysteine was added to neutralize the supernatant used for MG estimation, and the final volume was madeup to $1 \mathrm{~mL}$. The formation of product $N$ - $\alpha$-acetyl-S-(1-hydroxy-2-oxo-prop-1-yl) cysteine after $10 \mathrm{~min}$ was recorded at $288 \mathrm{~nm}$ using a spectrophotometer (Beckman640D, USA). A known concentration of MG was used to generate the standard curve, and MG was expressed as $\mu \mathrm{mol} \mathrm{g}^{-1} \mathrm{FW}$.

\section{Estimation of physiological parameters}

Gas exchange parameters were determined when the plants were 26-weeks-old. Net photosynthesis $(\mathrm{Pn}), \mathrm{CO}_{2}$ assimilation rate $(A)$, stomatal conductance $(g s)$, transpiration rate $(E)$, intercellular $\mathrm{CO}_{2}$ concentration $(\mathrm{Ci})$, and $\mathrm{CO}_{2}$ resistance (Rs) were determined using an infrared gas analyzer (LCA-4 model; Analytical Development Company, Hoddesdon, England) and the uppermost fully expanded leaves. 
Estimation of leaf relative water content, proline, and glycinebetaine

The relative water content (RWC) in leaves was measured according to Yamasaki and Dillenburg [53], , and calculations were performed using the following formula:

RWC $(\%)=($ Fresh weight - Dry weight $/$ Turgid weight - Dry weight $)$ $\times 100$

Proline content was determined following the method of Bates, et al. [54]. Absorbance was recorded spectrophotometrically at $520 \mathrm{~nm}$ (Beckman $640 \mathrm{D}$, USA) using toluene as a blank.

The method of Grieve and Grattan [55] was used to estimate glycine betaine (GB). Absorbance was measured at $365 \mathrm{~nm}$ using a spectrophotometer, and calculations were performed using the reference standard for $G B$ (50-200 $\mathrm{mg} \mathrm{mL}^{-1}$ ).

\section{Extraction of enzymes and their assay}

Fresh leaves $(0.5 \mathrm{~g})$ were macerated using a chilled mortar and pestle in phosphate buffer $(0.1 \mathrm{M}, \mathrm{pH} 7.5)$ and ethylenediaminetetraacetic acid (EDTA, $0.5 \mathrm{mM}$ ). The homogenate was filtered through four layers of muslin cloth and subjected to centrifugation at $12,000 \mathrm{~g}$ for $10 \mathrm{~min}$ at $4^{\circ} \mathrm{C}$. The resulting supernatant was used for the enzyme assays.

Superoxide dismutase (SOD; EC1.15.1.1) activity was determined by measuring the ability of theenzyme to inhibit the photochemical reduction of nitrobluetetrazoliumchloride, as described by Beyer and Fridovich [56]. The absorbance of the reaction mixture was read at $560 \mathrm{~nm}$, and one unit of SOD activity (EU) was defined as the amount of enzyme required to inhibit $50 \%$ of the NBT photoreduction rate and expressed as $\mathrm{EU} \mathrm{mg} \mathrm{mg}^{-1}$ protein.

APX (EC 1.11.1.11) was assayed following a reduction in absorbance at $290 \mathrm{~nm}$ for $3 \mathrm{~min}$, with the activity expressed as EU mg ${ }^{-1}$ protein [57].

Catalase (CAT; EC 1.11.1.6) activity was measured using the method of Aebi [58], with the change in absorbance recorded at $240 \mathrm{~nm}$ for $3 \mathrm{~min}$. CAT activity was expressed as unit $\mathrm{mg}^{-1}$ protein.

To estimateglutathione reductase (GR; EC 1.6.4.2) activity, the method of Foyer and Halliwell [59] was used, and the reductionin absorbance measured at $340 \mathrm{~nm}$ for 3 min. The GR activity was expressed as EU mg ${ }^{-1}$ protein.

Glutathione-S-transferase (GST; EC 2.5.1.18) was estimated following Hasanuzzaman and Fujita [60], and the increase in absorbance measured at $340 \mathrm{~nm}$ for $3 \mathrm{~min}$ witha spectrophotometer (Beckman 640D, USA). The GST activity was expressed as EU $\mathrm{mg}^{-1}$ protein.

Monodehydroascorbate reductase (MDHAR; EC 1.6.5.4) activity was estimated following the method of Miyake and Asada [61]. The change in absorbance was observed at 340 $\mathrm{nm}$ for $3 \mathrm{~min}$, with the activity expressed as EU mg ${ }^{-1}$ protein.

The activity of dehydroascorbate reductase (DHAR; EC 1.8.5.1) was estimated using the method of Nakano, et al. [57]. The absorbance was read at $265 \mathrm{~nm}$ for $3 \mathrm{~min}$ using a spectrophotometer (Beckman640D, USA), with the activity expressed as EU $\mathrm{mg}^{-1}$ protein.

Glyoxalase I (EC: 4.4.1.5) activity was estimated according to the method of Hasanuzzaman, et al. [23]. The assay mixture contained $100 \mathrm{mM} \mathrm{K-P}$ buffer ( $\mathrm{pH} 7.0$ ), $15 \mathrm{mM}$ magnesium sulfate, $1.7 \mathrm{mM}$ GSH, and $3.5 \mathrm{mM}$ MG. The reaction was started by adding MG; the increase in absorbance was recorded at $240 \mathrm{~nm}$ using a spectrophotometer (Beckman 640D, USA) for $1 \mathrm{~min}$,

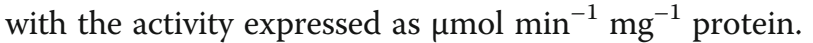

Glyoxalase II (EC: 3.1.2.6) was estimated using the method of Principato, et al. [62]. The reaction mixture contained $100 \mathrm{mM}$ Tris- $\mathrm{HCl}$ buffer (pH 7.2), $0.2 \mathrm{mM}$ DTNB, and $1 \mathrm{mM} S$-D-lactoylglutathione (SLG). The reaction was started by adding SLG, and theabsorbance at $412 \mathrm{~nm}$ was measured usinga spectrophotometer (Beckman 640D, USA). The activity was expressed as

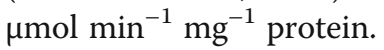

\section{Non-enzymatic antioxidants}

Ascorbate was extracted from fresh leaves $(0.8 \mathrm{~g})$ in $3 \mathrm{~mL}$ ice-cold metaphosphoric acid (5\%) containing $1 \mathrm{mM}$ EDTA and centrifuged at 10,000 rpm for $10 \mathrm{~min}$. The supernatant was distributed in two separate micro centrifuge tubes $(400 \mu \mathrm{l}$ in each) for the assay of total ascorbate (As + DAs) and reduced ascorbate. DAs concentration was then deduced from the difference. To each tube 200 $\mu \mathrm{l}$ of $10 \%$ TCA was added and vortexed mixed. $10 \mu \mathrm{l}$ of $\mathrm{NaOH}$ solution was then added to it, mixed and the mixture was centrifuged for $2 \mathrm{~min}$ in microcentrifuge. To 200 $\mu \mathrm{l}$ of the supernatant, $200 \mu \mathrm{l}$ of $150 \mathrm{mM}$ of $\mathrm{NaH}_{2} \mathrm{PO}_{4}$ and $200 \mu \mathrm{l}$ of water were added. To another $200 \mu \mathrm{l}$ of supernatant, $200 \mu \mathrm{l}$ of buffer and $100 \mu \mathrm{l}$ of $10 \mu \mathrm{l}$ of $10 \mathrm{mM}$ DDT were added and thoroughly mixed. Then $100 \mu \mathrm{l}$ of $0.5 \% \mathrm{~N}$ - Ethylmaleimide was added to each tube. Both samples were vortexed mixed and incubated at room temperature for $30 \mathrm{~min}$. To each tube was then added 400 $\mu \mathrm{l}$ of $10 \% \mathrm{TCA}, 400 \mu \mathrm{l}$ of $44 \% \mathrm{H}_{3} \mathrm{PO}_{4}, 4 \mu \mathrm{l}$ of $4 \%$ bipyridyl and $200 \mu \mathrm{l}$ of $3 \% \mathrm{FeCl}_{3}$. After vortexed mixing, samples were incubated at $33^{\circ} \mathrm{C}$ for $60 \mathrm{~min}$. The supernatant was then used for ascorbate analysis [63], and the absorbance was recorded at $525 \mathrm{~nm}$ on uv-vis spectrophotometer (Model Du 640, Beckman, USA).

The method of $\mathrm{Yu}$, et al. [64] was used to estimate the glutathione pool, and standard curves with known concentrations of GSH and GSSG were used for calculations. $0.5 \mathrm{~g}$ of fresh leaf was homogenized in $2 \mathrm{ml}$ of $5 \%$ sulphosalicylic acid under cold condition. The homogenate was centrifuged at $10,000 \mathrm{rpm}$ for $10 \mathrm{~min} .0 .5 \mathrm{ml}$ of 
aliquot was taken in a micro centrifuge tube, to which $0.6 \mathrm{ml}$ of reaction buffer and $40 \mu \mathrm{l}$ of DTNB was added. Absorbance for determination of GSH was read at 412 $\mathrm{nm}$ on uv- vis spectrophotometer (Model DU 640, Beckman, USA) after $2 \mathrm{~min}$. To the same tube $50 \mu \mathrm{l}$ of $\mathrm{NADPH}$ and $2 \mu \mathrm{l}$ of GR was added for the determination of total glutathione. Subtracting the reduced glutathione from total glutathione determines the oxidized glutathione. The reaction was allowed to run for $30 \mathrm{~min}$. at $25^{\circ} \mathrm{C}$. The change in absorbance at $412 \mathrm{~nm}$ on UV-VIS spectrophotometer (Model DU 640, Beckman, USA) was recorded. Values are corrected for the absorbance of supernatant and DTNB.

\section{Estimation of $\mathrm{Cd}$ and inorganic nutrients}

Shoot, root and leaf samples (100 mg each) were digested in $\mathrm{H}_{2} \mathrm{SO}_{4} / \mathrm{HNO}_{3}$ mixture $(1 / 5, \mathrm{v} / \mathrm{v})$ for $24 \mathrm{~h}$ and subsequently treated with $\mathrm{HNO}_{3} / \mathrm{HClO}_{4}$ mixture $(5 / 1, \mathrm{v} / \mathrm{v})$. Cadmium and other micronutrients $(\mathrm{B}, \mathrm{Cu}, \mathrm{Fe}, \mathrm{Mn}, \mathrm{Zn})$ and macronutrients $(\mathrm{S}, \mathrm{Mg}, \mathrm{Ca}, \mathrm{K}, \mathrm{P})$ in the solution were determined using a Perkin-Elmer (Analyst Model 300) atomic absorption spectrophotometer. The $\mathrm{Cd}$ content was expressed as $\mu \mathrm{mol} \mathrm{g^{-1 }} \mathrm{DW}$ and the other nutrients were expressed as $\mu \mathrm{g} \mathrm{g}^{-1} \mathrm{DW}$.

\section{Statistical analysis}

Data presented arethe means of five replicates with \pm SE. Data were analyzed following one-way analysis of variance (ANOVA) using SPSS software version 17. The $P$ values at 0.05 were considered significant. Mean values followed by the same lettersdo not significantly differ at $P<0.05$.

\section{Results}

Silicon and 24-EBL augmentedplant growth and biomass

Figure 1a-d shows the growth response (shoot and root DWs and lengths) of pea seedlings to $\mathrm{Cd}$ stress $\left(150 \mathrm{mg} \mathrm{L}^{-1}\right)$ and the individual and combined effects of EBL and Si. Cadmium stress alone reduced shoot and root lengths by $46.43 \%$ and $52.78 \%$, respectively, relative to theuntreated control. In control plants, EBL alone did not affect the shoot and root lengths of control plants. In Cd-stressed seedlings, shoot and root lengths increased by $28.89 \%$ and $41.71 \%$, respectively, with EBL, and by $34.70 \%$ and $51.31 \%$, respectively, with $\mathrm{Si}$, relative to seedlings exposed to $\mathrm{Cd}$ alone (Fig. 1a, b). However, the combined treatment of $\mathrm{EBL}+\mathrm{Si}$ enhanced shoot and root lengths by $57.47 \%$ and $82.66 \%$, respectively, relative to seedlings exposed to $\mathrm{Cd}$ alone.

Shoot and root DWs decreased by $52.78 \%$ and $62.35 \%$, respectively, in the $\mathrm{Cd}$-alone treatment, relative to the untreated control. However, the $\mathrm{Cd}+\mathrm{EBL}+\mathrm{Si}$ treatment increased shoot and root DWs by $96.87 \%$ and $42.85 \%$, respectively, relative to $\mathrm{Cd}$ alone, and was more effective than the individual treatments (Fig. 1c, d).
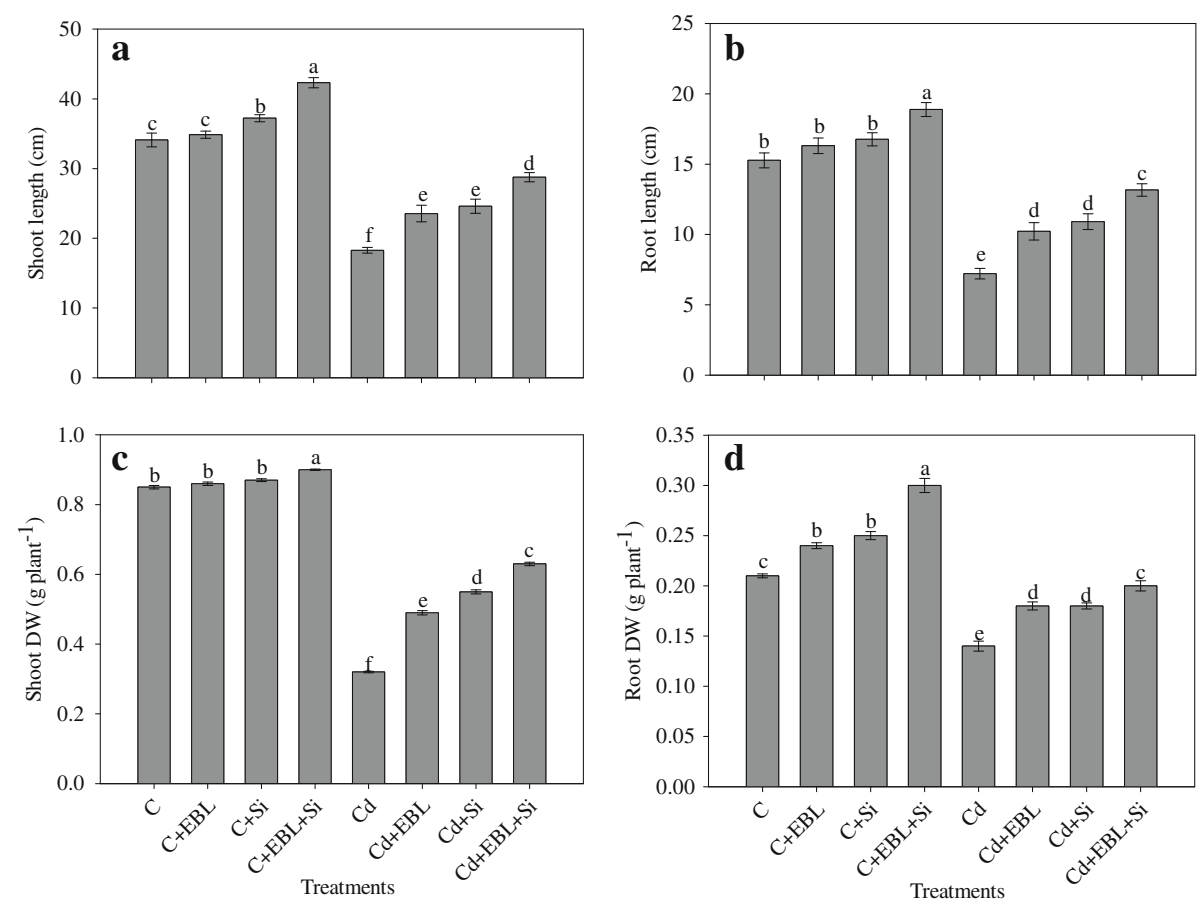

Fig. 1 Effect of 24-epibrassinolide and silicon individually and in combination on (a) shoot length, (b) root length, (c) shoot DW and (d) root DW in Pisum sativum seedlings under Cd stress. Data presented are the means \pm SE $(n=5)$. Different letters indicate significant difference at $P \leq 0.05$ 


\section{Silicon and 24-EBL augments pigment content}

Total chl and carotenoid contents declined by $33.09 \%$ and $51.51 \%$, respectively, in Cd-treated plants, relative to the control treatment. In Cd-treated seedlings, total chl and carotenoid contents increased by $19.35 \%$ and $18.75 \%$, respectively, with EBL, and by $25.80 \%$ and $31.25 \%$, respectively, with $\mathrm{Si}$, relative to seedlings exposed to $\mathrm{Cd}$ alone (Fig. 2a, b). The combined $\mathrm{Cd}+\mathrm{EBL}+\mathrm{Si}$ treatment increased total chl and carotenoid contents by $36.55 \%$ and $100 \%$, respectively, relative to $\mathrm{Cd}$ alone, and was more effective than the individual treatments.

\section{Silicon and 24-EBL improved photosynthetic efficiency}

The effects of Cd, EBL, and $\mathrm{Si}$ on chlorophyll fluorescence parameters are shown in Fig. 2c-f. The Cd-alone treatment significantly reduced $\mathrm{Fv} / \mathrm{Fm}$ (by $32.60 \%$ ), ФPSII (by 27.27\%), and qP (by 19.04\%) but increased NPQ (by $51.02 \%$ ),relative to untreated controlseedlings.
Individual applications of EBL and $\mathrm{Si}$ increased $\mathrm{Fv} / \mathrm{Fm}$, ФPSII, and qPanddecreased NPQ in Cd-treated and control seedlings. The combined $\mathrm{Cd}+\mathrm{EBL}+\mathrm{Si}$ treatment was more effective, with $\mathrm{Fv} / \mathrm{Fm}$, ФPSII, and qPincreasing by $41.93 \%, 45.83 \%$, and $29.41 \%$, respectively, and NPQ decreasing by $29.72 \%$, compared to $\mathrm{Cd}$ alone.

\section{Silicon and 24-EBL modulated physiological status}

The Cd-alone treatment reduced all the gas exchange parameters, i.e., $P n, A, g s$, and $E$ by $46.17 \%, 56.26 \%$, $80.65 \%$, and $73.00 \%$, respectively, relative to the control seedlings (Table 1). The Cd +EBL treatment increased $P n$ by $24.61 \%, A$ by $27.67 \%$, gs by $137.28 \%$, and $E$ by 93.18\%, relative to $\mathrm{Cd}$ alone. The $\mathrm{Cd}+\mathrm{Si}$ treatment also enhanced all the parameters. The combined Cd + EBL $+\mathrm{Si}$ treatment had a more pronounced effect, increasing $P n$ by $64.67 \%, A$ by $68.53 \%$, gs by $425.42 \%$, and $E$ by $165.90 \%$, relative to $\mathrm{Cd}$ alone.
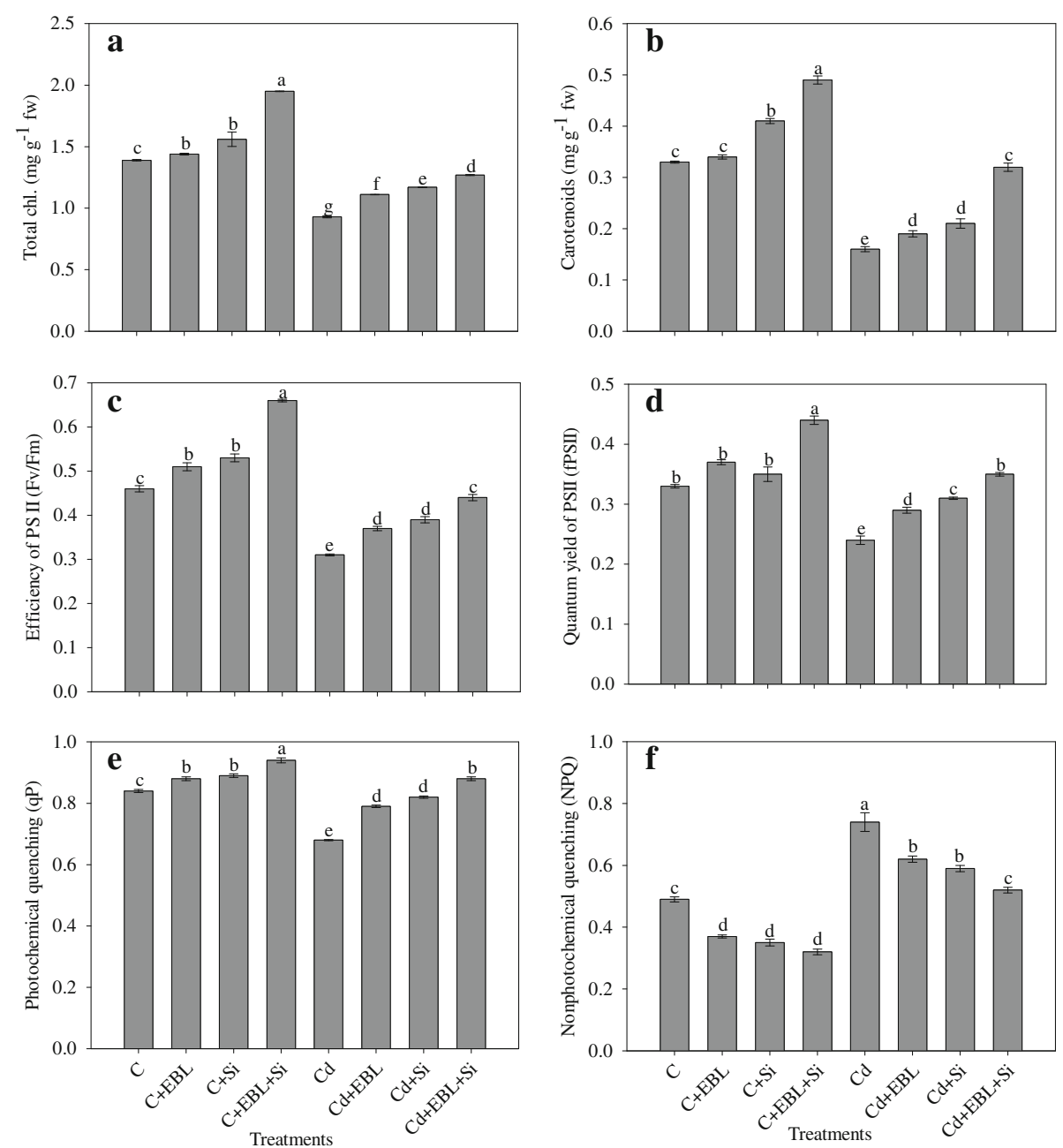

Fig. 2 Effect of 24-epibrassinolide and silicon individually and in combination on (a) total chlorophyll, (b) carotenoid content, (c) $F_{v} / F_{m}$, (d) $\Phi P S I I$, (e) $\mathrm{QP}$ and (f) NPQ in Pisum sativum seedlings under $\mathrm{Cd}$ stress. Data presented are the means $\pm \mathrm{SE}(n=5)$. Different letters indicate significant difference at $P \leq 0.05$ 
Table 1 Effect of 24-epibrassinolide and silicon individually and in combination on gas exchange parameters (Pn, A, gs, E) (E) RWC, Proline and glycine betaine content in Pisum sativum seedlings under $\mathrm{Cd}$ stress

\begin{tabular}{|c|c|c|c|c|c|c|c|}
\hline Treatment & $\begin{array}{l}\text { Net photosynthesis } \\
\text { rate } P n\left(\mu \mathrm{M} \mathrm{m}^{-1} \mathrm{~S}^{-1}\right)\end{array}$ & $\begin{array}{l}\mathrm{CO}_{2} \text { assimilation rate } \\
A\left(\mu \mathrm{M} \mathrm{CO} \mathrm{m}_{2} \mathrm{~S}^{-1}\right)\end{array}$ & $\begin{array}{l}\text { Stomatal conductance } \\
\text { gs }\left(\mathrm{mM} \mathrm{CO}_{2} \mathrm{~m}^{-2} \mathrm{~S}^{-1}\right)\end{array}$ & $\begin{array}{l}\text { Transpiration rate } \mathrm{E} \\
\left(\mathrm{mM} \mathrm{H}_{2} \mathrm{O} \mathrm{m}^{-2} \mathrm{~S}^{-1}\right)\end{array}$ & $\begin{array}{l}\text { Proline } \\
\left(\mu \mathrm{g} \mathrm{g}^{-1} \mathrm{fw}\right)\end{array}$ & $\begin{array}{l}G B \\
\left(\mu g g^{-1} f w\right)\end{array}$ & RWC (\%) \\
\hline $\bar{C}$ & $12.15 \pm 0.075^{c}$ & $13.88 \pm 0.031^{d}$ & $305 \pm 1.19^{d}$ & $1.63 \pm 0.014^{c}$ & $26.31 \pm 0.23^{f}$ & $2.04 \pm 0.011^{e}$ & $92.77 \pm 0.3^{b}$ \\
\hline $\mathrm{C}+\mathrm{EBL}$ & $12.37 \pm 0.073^{c}$ & $14.03 \pm 0.027^{c}$ & $380 \pm 2.671^{b}$ & $1.77 \pm 0.022^{b}$ & $27.44 \pm 0.13^{\mathrm{e}}$ & $2.05 \pm 0.016^{\mathrm{e}}$ & $93.52 \pm 0.508^{b}$ \\
\hline $\mathrm{C}+\mathrm{Si}$ & $13.01 \pm 0.079^{b}$ & $14.95 \pm 0.08^{b}$ & $385 \pm 1.682^{b}$ & $1.75 \pm 0.018^{b}$ & $27.15 \pm 0.15^{e}$ & $2.17 \pm 0.03^{d}$ & $93.77 \pm 0.316^{b}$ \\
\hline $\mathrm{C}+\mathrm{EBL}+\mathrm{Si}$ & $14.21 \pm 0.091^{a}$ & $16.07 \pm 0.092^{\mathrm{a}}$ & $401 \pm 2.753^{a}$ & $1.88 \pm 0.029^{a}$ & $28.37 \pm 0.25^{d}$ & $2.23 \pm 0.039^{d}$ & $95.42 \pm 0.125^{a}$ \\
\hline $\mathrm{Cd}$ & $6.54 \pm 0.022^{f}$ & $6.07 \pm 0.025^{9}$ & $59 \pm 3.695^{9}$ & $0.44 \pm 0.028^{f}$ & $115 \pm 1.7^{c}$ & $4.93 \pm 0.036^{c}$ & $55.49 \pm 0.511^{\mathrm{e}}$ \\
\hline $\mathrm{Cd}+\mathrm{EBL}$ & $8.15 \pm 0.034^{\mathrm{e}}$ & $7.75 \pm 0.044^{f}$ & $140 \pm 3.391^{\mathrm{e}}$ & $0.85 \pm 0.011^{\mathrm{e}}$ & $125 \pm 1.59^{b}$ & $5.74 \pm 0.05^{b}$ & $74.21 \pm 0.276^{d}$ \\
\hline $\mathrm{Cd}+\mathrm{Si}$ & $8.65 \pm 0.035^{e}$ & $7.81 \pm 0.043^{f}$ & $120 \pm 2.372^{f}$ & $0.89 \pm 0.012^{\mathrm{e}}$ & $129 \pm 1.62^{b}$ & $5.87 \pm 0.053^{b}$ & $76.84 \pm 0.588^{d}$ \\
\hline $\mathrm{Cd}+\mathrm{EBL}+\mathrm{Si}$ & $10.77 \pm 0.055^{d}$ & $10.23 \pm 0.063^{\mathrm{e}}$ & $310 \pm 1.12^{c}$ & $1.17 \pm 0.018^{d}$ & $154 \pm 1.74^{\mathrm{a}}$ & $6.14 \pm 0.072^{\mathrm{a}}$ & $88.42 \pm 0.155^{c}$ \\
\hline
\end{tabular}

Data presented are the means \pm SE $(n=5)$. Different letters next to the number indicate significant difference at $P \leq 0.05$

Silicon and 24-EBL ameliorated proline, glycine betaine and leaf relative water contents

Cadmium stress alone reduced RWC by $40.18 \%$, relative to the control. The $\mathrm{Cd}+\mathrm{EBL}, \mathrm{Cd}+\mathrm{Si}$, and $\mathrm{Cd}+\mathrm{EBL}+$ Si treatments increased RWC by $33.73 \%, 38.47 \%$, and $59.34 \%$, respectively, relative to $\mathrm{Cd}$ alone (Table 1 ).

The Cd-alone treatment increased proline and GB contents by 4.37 -fold and 2.41 -fold, respectively, relative to the control. These values were further increased with EBL (1.08-fold for proline and 1.16-fold for GB), Si (1.12-fold and 1.19-fold, respectively) and EBL + Si combined (1.33-fold and 1.24-fold, respectively) (Table 1).

\section{Silicon and 24-EBL reduced hydrogen peroxide MDA} contents, and electrolyte leakage and methyl glyoxalase Cadmium stress alone increased $\mathrm{H}_{2} \mathrm{O}_{2}$ production by $325.49 \%$, relative to the control seedlings. The $\mathrm{Cd}+$ $\mathrm{EBL}, \mathrm{Cd}+\mathrm{Si}$, and $\mathrm{Cd}+\mathrm{EBL}+\mathrm{Si}$ treatments decreased $\mathrm{H}_{2} \mathrm{O}_{2}$ by $27.02 \%, 32.43 \%$, and $64.24 \%$, respectively, relative to $\mathrm{Cd}$ alone (Fig. 3a).

Cadmium stress alone increased lipid peroxidation (estimatedfrom MDA content) by $70.71 \%$, relative to the control seedlings. The $\mathrm{Cd}+\mathrm{EBL}, \mathrm{Cd}+\mathrm{Si}$, and $\mathrm{Cd}+\mathrm{EBL}+\mathrm{Si}$ treatments decreased MDA content by $10.63 \%$, $14.00 \%$, and $29.03 \%$, respectively, relative to $\mathrm{Cd}$ alone (Fig. $3 \mathrm{~b}$ ).

Cadmium stress alone increased electrolyte leakage by 409.93\%, relative to the control. The $\mathrm{Cd}+\mathrm{EBL}, \mathrm{Cd}+\mathrm{Si}$, and $\mathrm{Cd}+\mathrm{EBL}+\mathrm{Si}$ treatments reduced electrolyte leakage by $20.04 \%, 24.03 \%$, and $46.06 \%$, respectively, relative to $\mathrm{Cd}$ alone (Fig. 3c).

Cadmium stress alone increased MG accumulation by $80.70 \%$, relative to the control. The $\mathrm{Cd}+\mathrm{EBL}, \mathrm{Cd}+$ $\mathrm{Si}$, and $\mathrm{Cd}+\mathrm{EBL}+\mathrm{Si}$ treatments decreased MG by $20.94 \%, 20.33 \%$, and $32.75 \%$, respectively, relative to $\mathrm{Cd}$ alone (Fig. 3d).

\section{Silicon and 24-EBL modulated antioxidant activity}

The Cd-alone treatment increased SOD activity by $152.92 \%$, relative to the control treatment. The $\mathrm{Cd}+$
$\mathrm{EBL}, \mathrm{Cd}+\mathrm{Si}$, and $\mathrm{Cd}+\mathrm{EBL}+\mathrm{Si}$ treatments further enhanced this activity by $12.00 \%, 24.23 \%$, and $35.93 \%$, respectively (Fig. 4a).

Cadmium stress alone increased CAT activity by $28.96 \%$, relative to the control treatment. The $\mathrm{Cd}+\mathrm{EBL}$, $\mathrm{Cd}+\mathrm{Si}$, and $\mathrm{Cd}+\mathrm{EBL}+\mathrm{Si}$ treatments further enhanced this activity by $32.31 \%, 41.45 \%$, and $78.91 \%$, respectively (Fig. 4b).

Cadmium stress alone increased GST activity by $57.51 \%$, relative to the control. The $\mathrm{Cd}+\mathrm{EBL}, \mathrm{Cd}+\mathrm{Si}$, and $\mathrm{Cd}+$ $\mathrm{EBL}+\mathrm{Si}$ treatments further enhanced this activity by 20.44\%, 22.11\%, and 50.80\%, respectively (Fig. 4c).

The Cd-alone treatment increased APX activity by $118.35 \%$, relative to the control. The $\mathrm{Cd}+\mathrm{EBL}, \mathrm{Cd}+\mathrm{Si}$, and $\mathrm{Cd}+\mathrm{EBL}+\mathrm{Si}$ treatments further enhanced this activity by $18.80 \%, 20.35 \%$, and $53.31 \%$, respectively (Fig. $5 a$ ).

Cadmium stress alone increased GR activity by $84.32 \%$, relative to the control. The $\mathrm{Cd}+\mathrm{EBL}, \mathrm{Cd}+\mathrm{Si}$, and $\mathrm{Cd}+\mathrm{EBL}+\mathrm{Si}$ treatments further enhanced this activity by $4.08 \%, 7.82 \%$, and $29.42 \%$, respectively (Fig. $5 \mathrm{~b}$ ).

The Cd-alone treatment reduced MDHAR and DHAR activities (Fig. 5c, d) by $45.63 \%$ and $40.03 \%$, respectively, relative to the control. The $\mathrm{Cd}+\mathrm{EBL}$ treatment increased the activity of MDHAR by $40.61 \%$ and DHAR by $31.35 \%$, relative to the $\mathrm{Cd}$-alone treatment. The combined $\mathrm{Cd}+\mathrm{EBL}+\mathrm{Si}$ treatment further enhanced MDHAR and DHAR activities by $57.56 \%$ and $49.62 \%$, respectively, relative to the Cd-alone treatment.

Cadmium stress alone reduced the AsA content by $60.00 \%$, relative to the control (Fig. 6a). The $\mathrm{Cd}+\mathrm{EBL}$, $\mathrm{Cd}+\mathrm{Si}$, and $\mathrm{Cd}+\mathrm{EBL}+\mathrm{Si}$ treatments improved AsA accumulation by $50.00 \%, 62.50 \%$, and $112.50 \%$, respectively, relative to the $\mathrm{Cd}$-alone treatment.

The Cd-alone treatment increased GSH content by $68.61 \%$, relative tothe control. The $\mathrm{Cd}+\mathrm{EBL}, \mathrm{Cd}+\mathrm{Si}$, and $\mathrm{Cd}+\mathrm{EBL}+\mathrm{Si}$ treatments further enhanced $\mathrm{GSH}$ content by $23.08 \%, 33.79 \%$, and $50.91 \%$, respectively, relative to the $\mathrm{Cd}$-alone treatment (Fig. 6b). 

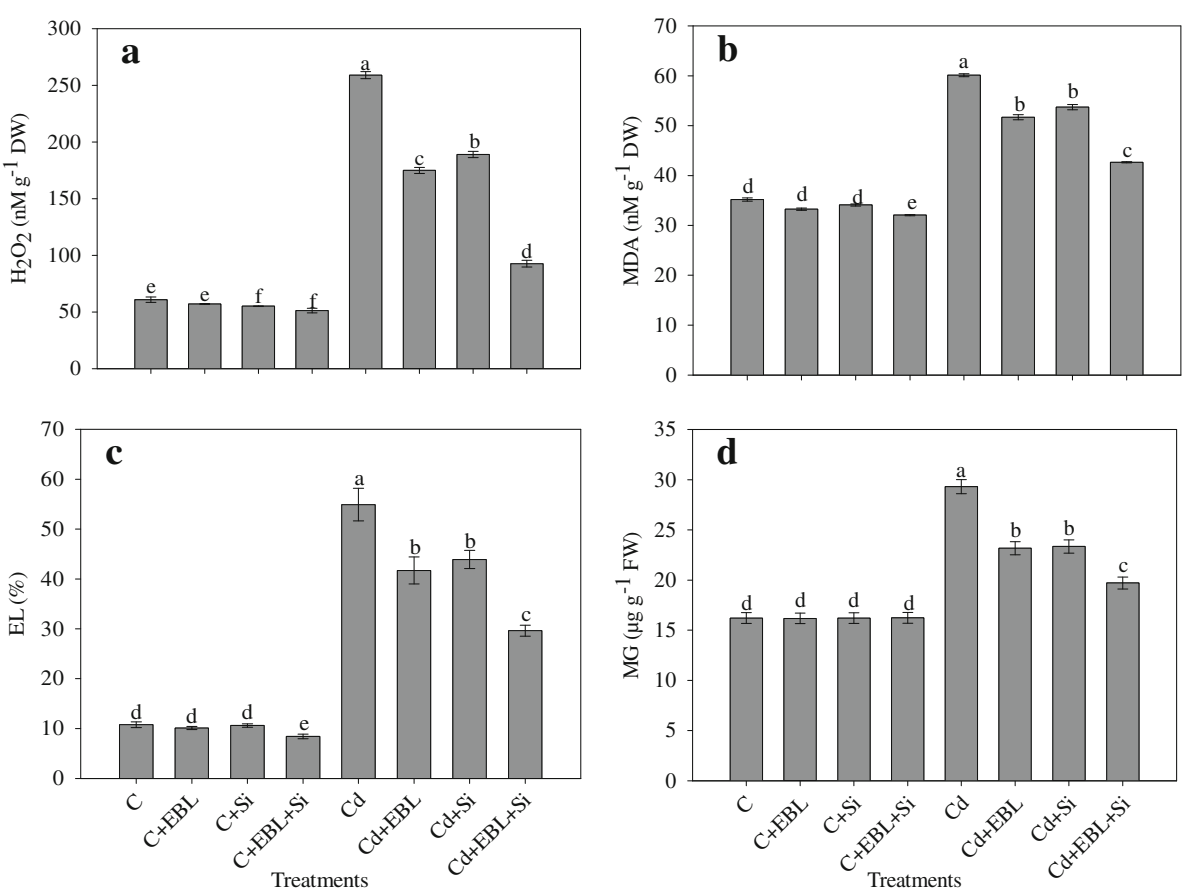

Fig. 3 Effect of 24-epibrassinolide and silicon individually and in combination on (a) $\mathrm{H}_{2} \mathrm{O}_{2}$ content, (b) MDA content (c) EL and (d) MG in Pisum sativum seedlings under $\mathrm{Cd}$ stress. Data presented are the means $\pm \mathrm{SE}(n=5)$. Different letters indicate significant difference at $P \leq 0.05$
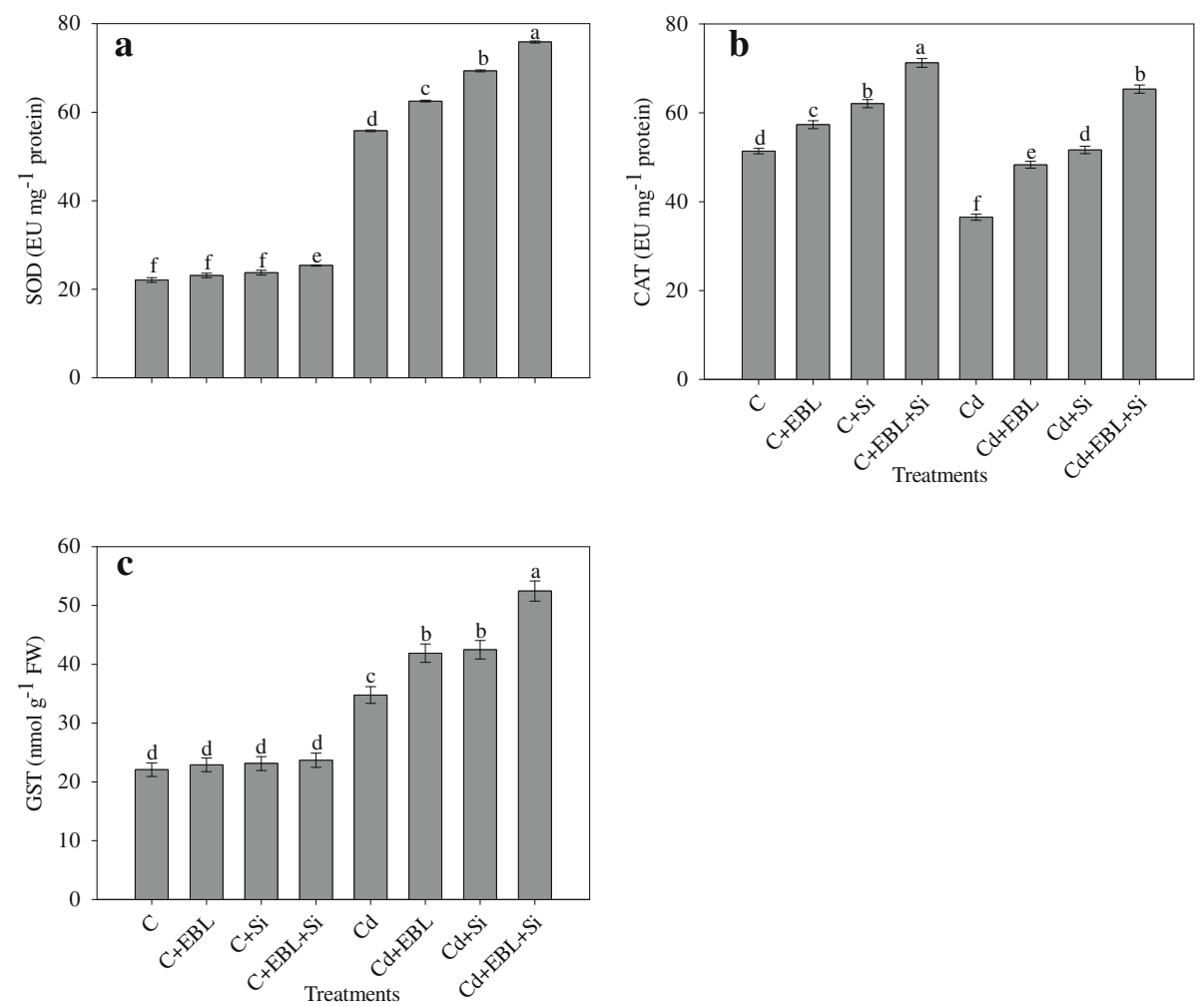

Fig. 4 Effect of 24-epibrassinolide and silicon individually and in combination on (a) SOD, (b) CAT and (c) GST in Pisum sativum seedlings under $\mathrm{Cd}$ stress. Data presented are the means $\pm \mathrm{SE}(n=5)$. Different letters indicate significant difference at $P \leq 0.05$ 

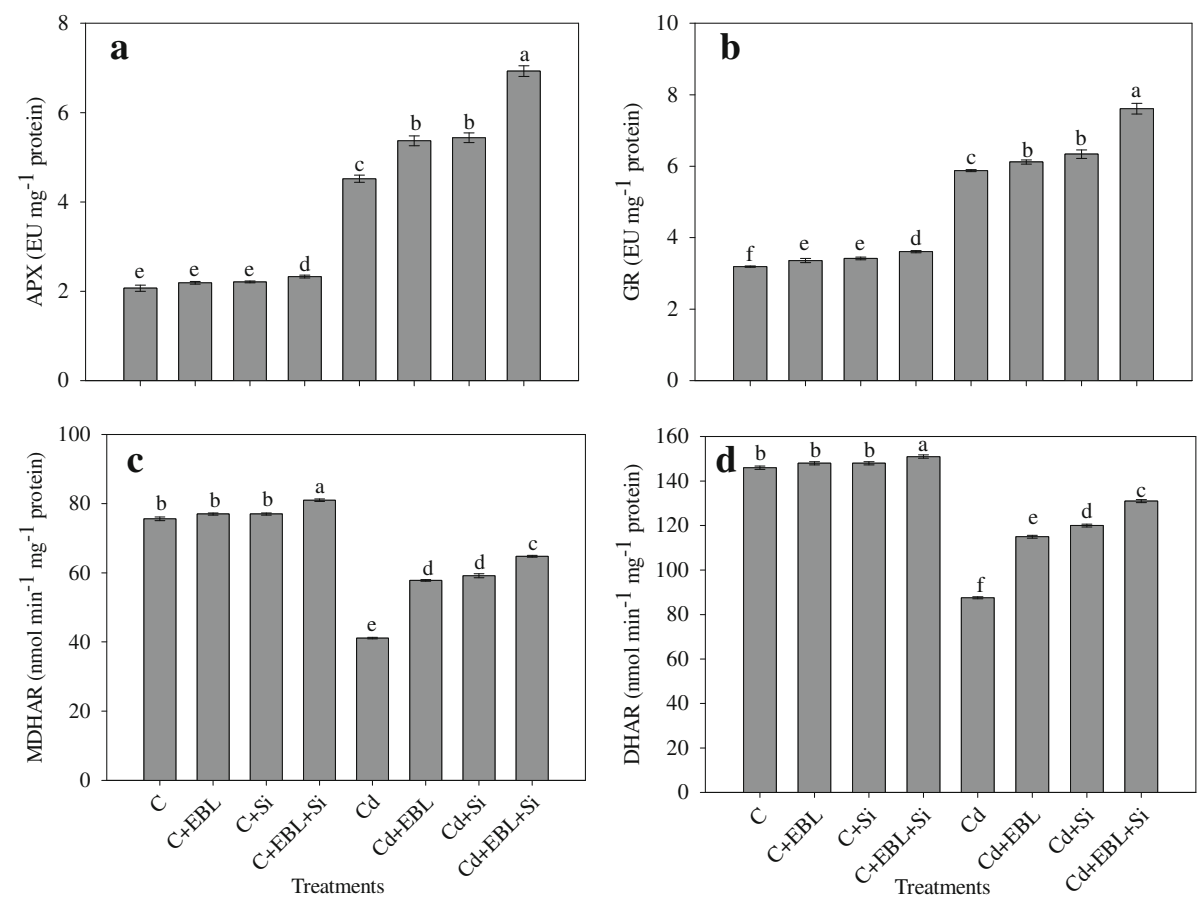

Fig. 5 Effect of 24-epibrassinolide and silicon individually and in combination on (a) APX, (b) GR, (c) MDHARand (d) DHAR in Pisum sativum seedlings under $\mathrm{Cd}$ stress. Data presented are the means $\pm \operatorname{SE}(n=5)$. Different letters indicate significant difference at $P \leq 0.05$

Cadmium stress alone reduced GSSG content by $35.43 \%$,relative to the controls. The Cd $+\mathrm{EBL}, \mathrm{Cd}+\mathrm{Si}$, and $\mathrm{Cd}+\mathrm{EBL}+\mathrm{Si}$ treatments further enhanced GSSH content by $41.71 \%, 44.83 \%$, and $56.97 \%$, respectively, relative to the Cd-alone treatment (Fig. 6c).

\section{Silicon and 24-EBL maintained Gly I and Gly II activities}

Cadmium stress alone enhanced Gly I activity by $54.41 \%$, relative to the control. The $\mathrm{Cd}+\mathrm{EBL}, \mathrm{Cd}+\mathrm{Si}$, and $\mathrm{Cd}+\mathrm{EBL}+\mathrm{Si}$ treatments further increased this activity by $25.71 \%, 26.66 \%$, and $32.38 \%$, respectively, relative to $\mathrm{Cd}$ alone (Fig. 7a).

TheCd-alone treatment reduced Gly II activity by $32.46 \%$, relative to the control. The $\mathrm{Cd}+\mathrm{EBL}, \mathrm{Cd}+\mathrm{Si}$, and $\mathrm{Cd}+\mathrm{EBL}+\mathrm{Si}$ treatments enhanced this activity by $17.30 \%, 21.15 \%$, and $32.69 \%$, respectively, relative to $\mathrm{Cd}$ alone (Fig. 7b).

\section{Silicon and 24-EBL reduced Cd accumulation}

Cadmium accumulated in different plant parts in the following order: roots $>$ shoots $>$ leaves. EBL supplementation to Cd-stressed seedlings decreased $\mathrm{Cd}$ accumulation in the roots, shoots, and leaves by $38.69 \%, 28.47 \%$, and $48.56 \%$, and similar values were observed after Si supplementation. The combined $\mathrm{Cd}+\mathrm{EBL}+\mathrm{Si}$ treatment further reduced $\mathrm{Cd}$ accumulation by $60.15 \%$ in roots, $48.63 \%$ in shoots, and $68.42 \%$ in leaves, relative to $\mathrm{Cd}$ alone (Table 2).
Silicon and 24-EBL enhanced mineral uptake

The Cd-alone treatment impaired mineral uptake in the shoots and roots (Table 3 ). In the shoots, cadmium reduced $\mathrm{S}, \mathrm{Mg}, \mathrm{Ca}, \mathrm{P}$, and $\mathrm{K}$ contents by $34.69 \%, 58.33 \%$, $43.47 \%, 48.62 \%$, and $57.55 \%$, respectively, relative to the control. Supplementation with EBL or Si to Cd-treated plants resulted in smallerreductions in the above macronutrients; however, the combined $\mathrm{Cd}+\mathrm{EBL}+\mathrm{Si}$ treatment enhanced S uptake by $41.76 \%, \mathrm{Mg}$ by $114.28 \%$, Ca by $56.92 \%, \mathrm{~K}$ by $47.88 \%$, and $\mathrm{P}$ by $64.47 \%$, relative to their respective levels with $\mathrm{Cd}$ alone. In the roots, the Cd-alone treatment reduced $\mathrm{S}, \mathrm{Mg}, \mathrm{Ca}, \mathrm{K}$, and $\mathrm{P}$ contents by $48.36 \%, 40.85 \%, 42.78 \%, 51.64 \%$, and $51.00 \%$, respectively, relative to the control. Supplementation with $\mathrm{EBL}$ or Si to Cd-treated plants enhanced the uptake of these elements, but the combined $\mathrm{Cd}+\mathrm{EBL}+\mathrm{Si}$ treatment was more effective, enhancing S uptake by $56.08 \%, \mathrm{Mg}$ by $37.47 \%$, Ca by $67.82 \%$, K by $94.97 \%$, and P by $56.12 \%$, relative to Cdalone (Table 3 ).

The Cd-alone treatment reduced the uptake of micronutrients in the shoots and roots (Table 4). In the shoots, $\mathrm{Cd}$ alone reduced $\mathrm{B}, \mathrm{Cu}, \mathrm{Fe}, \mathrm{Mn}$, and $\mathrm{Zn}$ by $45.00 \%, 28.48 \%, 27.05 \%, 56.07 \%$, and $37.58 \%$, respectively, relative to thecontrol. Supplementation with EBL or $\mathrm{Si}$, individually or in combination, enhanced the uptake of these micronutrients into shoots. In the roots, $\mathrm{Cd}$ alone reduced $\mathrm{B}, \mathrm{Cu}, \mathrm{Fe}, \mathrm{Mn}$, and $\mathrm{Zn}$ by $43.64 \%$, $31.39 \%, 34.52 \%, 40.07 \%$, and $41.32 \%$, respectively, 

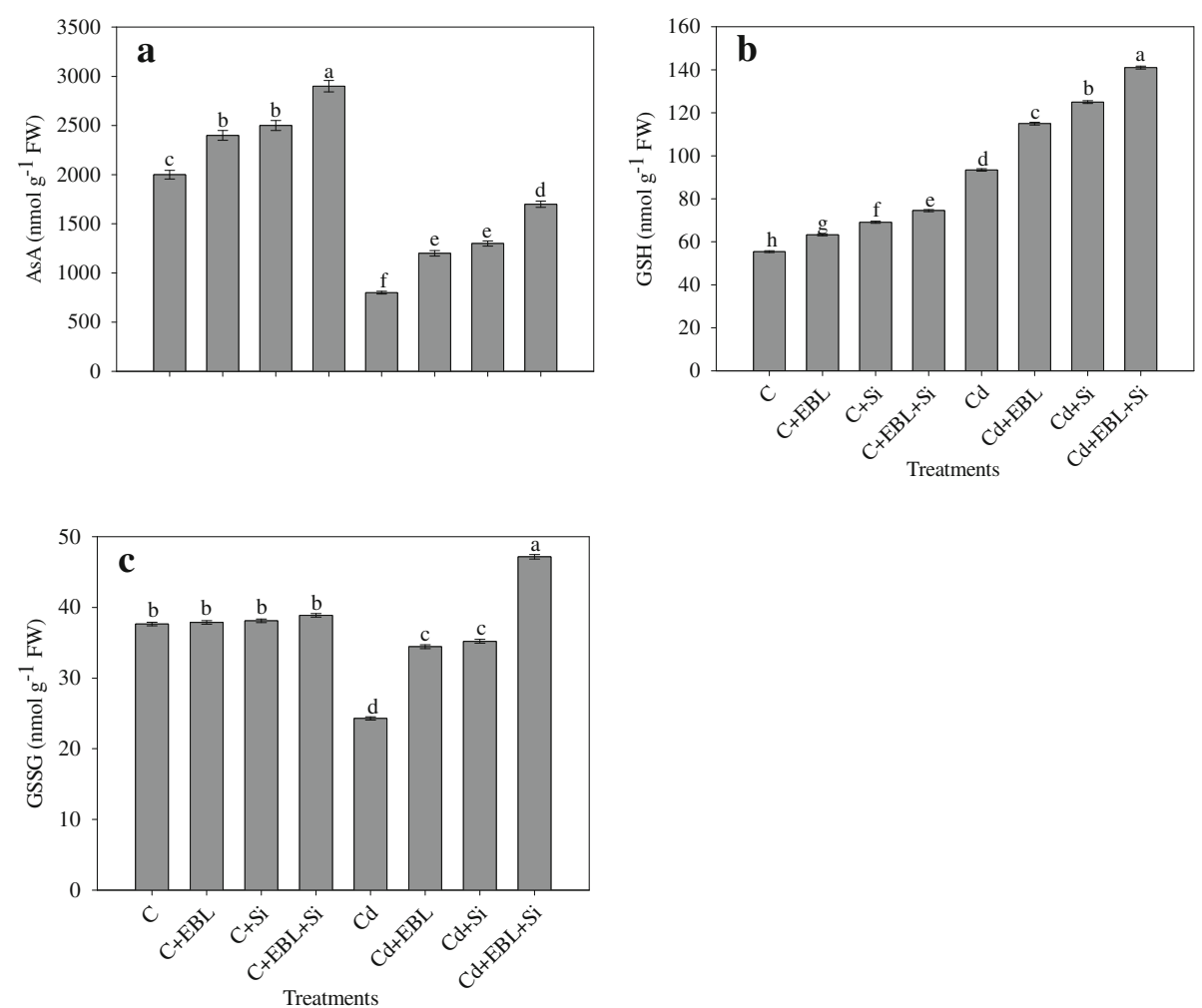

Fig. 6 Effect of 24-epibrassinolide and silicon individually and in combination on (a) AsA, (b) GSH and (c) GSSG in Pisum sativum seedlings under $\mathrm{Cd}$ stress. Data presented are the means $\pm \mathrm{SE}(n=5)$. Different letters indicate significant difference at $P \leq 0.05$

relative to the control. The $\mathrm{Cd}+\mathrm{EBL}+\mathrm{Si}$ treatment was more effectiveat enhancing micronutrient uptake than the individual treatments, with increases of $64.54 \%$ in B, $35.68 \%$ in $\mathrm{Cu}, 36.88 \%$ in $\mathrm{Fe}, 39.37 \%$ in $\mathrm{Mn}$, and $53.28 \%$ in $\mathrm{Zn}$, relative to $\mathrm{Cd}$ alone.

\section{Discussion}

Silicon and 24-EBL augmented plant growth and biomass In this study, the effect of $\mathrm{Si}$ and 24-EBL on the growth, physiology, and metabolic alterations in pea seedlings with and without $\mathrm{Cd}$ stresswas investigated by evaluating growth, chl content, photosynthetic efficiency, osmolyte accumulation, antioxidant enzymatic responses, and mineral nutrient contents. Numerous studies have shown that $\mathrm{Si}$ and 24-EBL have ameliorative effects against a wide range of abiotic and biotic stresses [2, 34, 38, 39, 65]. However, at low concentration, $\mathrm{Si}$ can also increase plant growth and development without any apparent toxicity [66]. In our study, the growth of pea plants declined under $\mathrm{Cd}$ stress (Table 1). The subsequent application of $\mathrm{Si}$ or
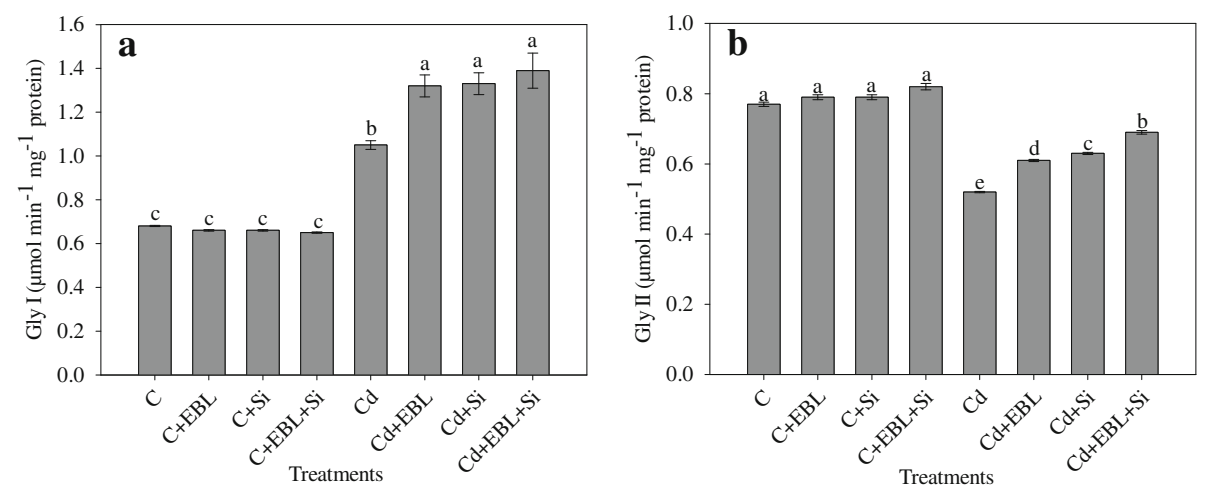

Fig. 7 Effect of 24-epibrassinolide and silicon individually and in combination on (a) Gly I and (b) Gly II in Pisum sativum seedlings under Cd stress. Data presented are the means $\pm \mathrm{SE}(n=5)$. Different letters indicate significant difference at $P \leq 0.05$ 
Table 2 Effect of 24-epibrassinolide and silicon individually and in combination on accumulation of Cd in root, shoot and leaf in Pisum sativum seedlings under Cd stress

\begin{tabular}{llll}
\hline Treatments & Root Cd $\left(\mu \mathrm{g} \mathrm{g}^{-1} \mathrm{FW}\right)$ & Shoot Cd $\left(\mu \mathrm{g} \mathrm{g}^{-1} \mathrm{FW}\right)$ & $\mathrm{Leaf} \mathrm{Cd}\left(\mu \mathrm{g} \mathrm{g} \mathrm{FW}^{-1}\right.$ \\
\hline $\mathrm{C}$ & $\mathrm{ND}$ & $\mathrm{ND}$ & $\mathrm{ND}$ \\
$\mathrm{C}+\mathrm{EBL}$ & $\mathrm{ND}$ & $\mathrm{ND}$ & $\mathrm{ND}$ \\
$\mathrm{C}+\mathrm{Si}$ & $\mathrm{ND}$ & $\mathrm{ND}$ & $\mathrm{ND}$ \\
$\mathrm{C}+\mathrm{EBL}+\mathrm{Si}$ & $\mathrm{ND}$ & $\mathrm{ND}$ & $\mathrm{ND}$ \\
$\mathrm{Cd}$ & $29.64 \pm 0.28^{\mathrm{a}}$ & $10.22 \pm 0.13^{\mathrm{a}}$ & $4.18 \pm 0.03^{\mathrm{a}}$ \\
$\mathrm{Cd}+\mathrm{EBL}$ & $18.17 \pm 0.20^{\mathrm{b}}$ & $7.31 \pm 0.07^{\mathrm{b}}$ & $2.15 \pm 0.005^{\mathrm{b}}$ \\
$\mathrm{Cd}+\mathrm{Si}$ & $17.55 \pm 0.18^{\mathrm{b}}$ & $7.37 \pm 0.07^{\mathrm{b}}$ & $2.08 \pm 0.005^{\mathrm{b}}$ \\
$\mathrm{Cd}+\mathrm{EBL}+\mathrm{Si}$ & $11.81 \pm 0.12^{\mathrm{c}}$ & $5.25 \pm 0.04^{\mathrm{c}}$ & $1.32 \pm 0.001^{\mathrm{c}}$ \\
\hline Da & &
\end{tabular}

Data presented are the means \pm SE $(n=5)$. Different letters next to the number indicate significant difference at $P \leq 0.05$

24-EBL, either individually or in combination, augmented the growth attributes in $\mathrm{Cd}$-stressed plants (Table 1). Stimulation of growth by $\mathrm{Si}$ in $\mathrm{Cd}$ stressed plants has been reported in cucumber [67], wheat [68], cotton [69], and peanut [43]. Similarly, 24-EBL supplementation has improved growth of $\mathrm{Cd}$-stressed plants including tomato [40], radish [65], and bean [41]. Enhanced growth parameters could be due to the ability of 24-EBL to control cell elongation and division via upregulation of xyloglucan endo-transglycosylase $[70,71]$ or to a dilution effect of $\mathrm{Si}$ that decreases metal uptake or increases nutrient uptake by plants, resulting in higher photosynthetic efficiency [8]. $\mathrm{Si}$ application has increased both shoot and root DW in many plant species under Cd stress, including maize [72], wheat [6], and rice [73]. Co-application of 24-EBL and Si had pronounced effects on the growth and biomass of pea seedlings under $\mathrm{Cd}$ stress likelydue to synergistic or additive effects.

\section{Silicon and 24-EBL restored pigment content and photosynthetic efficiency}

In this study, Cd-stressed pea seedlings had lower chlorophyll and carotenoid contents (Table 2). Reductions in chlorophyll and carotenoid synthesis in response to $\mathrm{Cd}$ stress may be due to the inhibitory effect of $\mathrm{Cd}$ on the enzymes associated with pigment biosynthesis [74].
Deleterious effects of $\mathrm{Cd}$ stress have been reported in maize:Cd reduced chlorophyll synthesis [75], the photochemical quantum yield of photosystem II ( $\left.\Phi_{\mathrm{PSII}}\right)$, and the $\mathrm{CO}_{2}$ fixation rate [76]. Si application enhanced the chlorophyll pigment and carotenoidcontents of pea seedlings (Table 2). Exogenous application of Si has had positive effects on chlorophyll biosynthesis and photosynthetic machinery in Cd-stressed maize [77], wheat [23], and pea [8]. $\mathrm{Wu}$, et al. [78] reported that Si supplementation reduced $\mathrm{Cd}$ translocation in cucumber roots, thereby decreasing the interference of $\mathrm{Cd}$ complexation with photosynthetic machinery. Sa [79] found that photosynthetic pigments were restoredfollowing exogenous application of $\mathrm{Si}$ in cotton seedlings. Stimulatory effects of Si on photosynthetic processes could be dueto impaired heavy metal uptake, which would facilitate PSI and PSII activation [80]. Si ameliorates the decline in chlorophyll fluorescence by inhibiting $\mathrm{Cd}$ uptake as $\mathrm{Si}$ induces modifications in $\mathrm{Cd}$ binding properties of cell wall [81]. Exogenous application of $500 \mathrm{mg} \mathrm{SiO}_{2}$ to Cd-stressed Allium sativum L. seedlings increased the quantum efficiency [82]. Similarly, exogenous application of EBL to Cd-stressed Raphanus sativus enhanced growth byimproving the photosynthetic pigment concentration [83]. Foliar application of 24-EBL ameliorated the damage to chlorophyll and carotenoid contents, which supportsthe findings of studies in Brassica

Table 3 Effect of 24-epibrassinolide and silicon individually and in combination on macronutrients (S, Mg, Ca, K and P) in shoot and root in Pisum sativum seedlings under Cd stress

\begin{tabular}{|c|c|c|c|c|c|c|c|c|c|c|}
\hline $\operatorname{Treatments}\left(\mu \mathrm{g} \mathrm{g}{ }^{-1} \mathrm{DW}\right)$ & Shoot S & Shoot Mg & Shoot Ca & Shoot K & Shoot P & Root S & Root Mg & Root Ca & Root K & Root P \\
\hline C & $95.26 \pm 0.905^{c}$ & $252 \pm 0.95^{c}$ & $115 \pm 0.45^{c}$ & $691 \pm 2.885^{c}$ & $450 \pm 3.72^{d}$ & $366 \pm 0.942^{d}$ & $776 \pm 1.26^{d}$ & $201 \pm 0.762^{c}$ & $1152 \pm 2.43^{d}$ & $200 \pm 0.945^{c}$ \\
\hline$C+E B L$ & $99.05 \pm$ & $262 \pm 0.976^{b}$ & $122 \pm 0.458^{b}$ & $5 \pm 2.96^{b}$ & $498 \pm$ & $385 \pm$ & $791 \pm 0.302^{b}$ & $211 \pm$ & $b^{b}$ & $995^{\mathrm{b}}$ \\
\hline $\mathrm{C}+\mathrm{Si}$ & $99.56 \pm 0.995^{b}$ & $259 \pm 0.966^{b}$ & $120 \pm 0.654^{b}$ & $702 \pm 1.95^{\mathrm{b}}$ & $508 \pm 4.06^{b}$ & $376 \pm 0.955^{c}$ & $788 \pm 0.586^{c}$ & $200 \pm 0.752^{c}$ & $1215 \pm 2.51^{c}$ & $224 \pm 0.992^{b}$ \\
\hline$+\mathrm{EBL}+\mathrm{Si}$ & $115 \pm 1.135^{\mathrm{a}}$ & $267 \pm 0.99^{\mathrm{a}}$ & 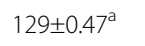 & $85^{\mathrm{a}}$ & $525 \pm 4.32^{\mathrm{a}}$ & $396 \pm 1.06$ & $820 \pm 1.422^{\mathrm{a}}$ & $225 \pm 0.788^{a}$ & $3^{a}$ & $37^{\mathrm{a}}$ \\
\hline $\mathrm{Cd}$ & $62.21 \pm 0.69^{9}$ & $105 \pm 0.422^{9}$ & $65 \pm 0.308^{9}$ & $355 \pm 1.445^{9}$ & $259 \pm 2.25^{\mathrm{h}}$ & $189 \pm 0.5975^{h}$ & $459 \pm 0.73^{h}$ & $115 \pm 0.438^{9}$ & $557 \pm 1.262^{h}$ & $98 \pm 0.502^{f}$ \\
\hline$d+E B L$ & $76.49 \pm 0.575^{e}$ & $189 \pm 0.662^{e}$ & $89 \pm 0.376^{e}$ & $466 \pm 1.905^{e}$ & $347 \pm 3.37^{9}$ & $266 \pm 0.7375^{f}$ & $587 \pm 1.146^{f}$ & $182 \pm 0.59^{e}$ & $889 \pm 1.792^{f}$ & $138 \pm 0.592^{e}$ \\
\hline $\mathrm{Cd}+\mathrm{Si}$ & $73.54 \pm 0.545^{f}$ & $173 \pm 0.636^{f}$ & $83 \pm 0.35^{f}$ & $452 \pm 1.88^{f}$ & $369 \pm 3.48^{f}$ & $259 \pm 0.7175^{9}$ & $523 \pm 1.042^{9}$ & $174 \pm 0.542^{f}$ & $823 \pm 1.754^{\mathrm{g}}$ & $139 \pm 0.612^{e}$ \\
\hline $\mathrm{d}+\mathrm{EBL}+\mathrm{Si}$ & $88.19 \pm 0.86^{d}$ & $225 \pm 0.844^{d}$ & $102 \pm 0.412^{d}$ & $525 \pm 2.11^{d}$ & $426 \pm 3.27^{e}$ & $295 \pm 0.78^{e}$ & $631 \pm 1.216^{\mathrm{e}}$ & $193 \pm 0.62^{d}$ & $1086 \pm 2.274^{e}$ & $153 \pm 0.657^{d}$ \\
\hline
\end{tabular}

Data presented are the means \pm SE $(n=5)$. Different letters next to the number indicate significant difference at $P \leq 0.05$ 
Table 4 Effect of 24-epibrassinolide and silicon individually and in combination on micronutrients (B, Cu, Fe, Mn and Zn) in shoot and root in Pisum sativum seedlings under $\mathrm{Cd}$ stress

\begin{tabular}{|c|c|c|c|c|c|c|c|c|c|c|}
\hline $\begin{array}{l}\text { eatments } \\
\left.\mathrm{g} \mathrm{g}^{-1} \mathrm{DW}\right)\end{array}$ & & & & & $n$ & $B$ & u & e & $n$ & Zn \\
\hline$C$ & & & & - & & 02 & $514^{b}$ & 34 & 5 & \\
\hline & & 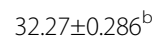 & 82 & & & & 12.3 .94 & & & 40.2210 .47 \\
\hline$+\mathrm{Si}$ & & $.07 \pm 0.288^{b}$ & & $35.11 \pm$ & $306^{\mathrm{a}}$ & $82^{a}$ & $1 \pm 0.524^{\mathrm{a}}$ & & & 50 \\
\hline The & $43.46 \pm 0.3$ & aרקב ח & r & $42.39=$ & $312^{a}$ & $30.95 \pm$ & 74.25 & $555 \pm 1.37^{\mathrm{a}}$ & $115 \pm$ & . \\
\hline & & $22.42 \pm 0$ & $124 \pm$ & 13.2 & & & & $03^{e}$ & $.79^{f}$ & 27 \\
\hline $\mathrm{Cd}+\mathrm{EBL}$ & $26.53 \pm 0.942^{d}$ & $25.77 \pm 0.256^{d}$ & $152 \pm 0.576^{d}$ & $24.29 \pm$ & $9.55 \pm 0.656^{d}$ & $19.35 \pm$ & $55.32 \pm 0.4$ & $398 \pm 3.14^{d}$ & $78.62 \pm 2.85^{e}$ & $36.91 \pm 0.35^{f}$ \\
\hline $\mathrm{A}+\mathrm{Si}$ & & & & & & & & & & \\
\hline$+\mathrm{EBL}$ & $33.42 \pm 0.278^{c}$ & $28.51 \pm 0.27^{c}$ & $165 \pm 0.596^{c}$ & $27.03 \pm 0.665^{d}$ & $35.26 \pm 0.282^{c}$ & $26.69 \pm$ & $63.92 \pm 0.484^{c}$ & $475 \pm 2.2^{c}$ & $82.44 \pm 0.88^{d}$ & $\pm 0.39^{e}$ \\
\hline
\end{tabular}

Data presented are the means $\pm \mathrm{SE}(n=5)$. Different letters next to the number indicate significant difference at $P \leq 0.05$

juncea L. [84] and Raphanus sativus L. [85]. Exogenous application of 24-EBL enhanced photosynthetic pigments andcarotenoidcontent due to its stimulatory effect on ribulose 1,5-bisphosphate carboxylase oxygenase activity [86]. EBL has improved photosynthesis by increasing the activity of Calvin cycle enzymes Co-application of EBL+Si to pea seedlings augmented chlorophyll content and carotenoid concentration, probably by modulating mineral uptake, particularly magnesium, which forms an integral part of chlorophyll molecules. Photochemical quenching $(\mathrm{qP})$ and quantum yield of PSII were highest in pea seedlings treated with $\mathrm{Si}+\mathrm{EBL}$, suggesting a cumulative stimulatory effect on photosynthetic efficiency with Si improving nutrient uptake and 24-EBL reducing the photo-damage caused by the increase in carotenoid concentration.

\section{Silicon and 24-EBL modulated physiological status and osmolyte accumulation}

$\mathrm{Cd}$-stressed pea seedlings had reduced physiological activities including photosynthetic rate, $\mathrm{CO}_{2}$ assimilation rate, stomatal conductance, and transpiration rate (Table 3 ). Physiological activity decreases with a reduction in enzymatic activity in the Calvin cycle and impaired electron transfer across the electron transport chain [16, 32]. Further, a significant reduction in stomatal conductance and relative water content was noted with $\mathrm{Cd}$ stress. Supplementation with $\mathrm{Si}$ or 24-EBL enhanced the physiological activities and relative water contentsin the Cd-stressed pea seedlings (Table 3). Si enhanced the activity of gas exchange characteristics, including net photosynthetic rate, stomatal conductance, transpiration rate, and water use efficiency, under $\mathrm{Cd}$ stress in cotton, rice, and cucumber $[67,87]$. Cadmium stress increased the photosynthetic rate and chlorophyll fluorescence in barley and wheat $[88,89]$. Si enhances Cd tolerance by increasing the instantaneous water use efficiency, carboxylation efficiency of ribulose 1,5-bisphosphate carboxylase oxygenase, and light use efficiency [80]. The stimulatory effect of Si on photosynthetic machinery might be due to reduced $\mathrm{Cd}$ translocation by plants with less damage to photosynthetic machinery [77]. EBL significantly enhances the photosynthetic rate in Cd-stressed tomato plants by modulating photosynthetic efficiency [90]. Co-application of $24 \mathrm{EBL}$ and $\mathrm{Si}$ improvedthe photosynthetic rate, $\mathrm{CO}_{2}$ assimilation rate, stomatal conductance, and transpiration rate in Cd-stressed pea seedlings, thereby confirming their stimulatory effects. Relative water content increased with the combined $\mathrm{Si}$ and 24-EBL treatment in both control and Cd-stressed pea seedlings. Enhanced relative water content was also observed in Cd-stressed Phaseolus vulgaris treated with 24-EBL [41] and was attributed to its inhibitory effect on ABA levels, which might be correlated with the normalization of water relations [91]. Si application increases the relative water content by modulating water use efficiency and stomatal conductance in plants under heavy metal stress [89]. The co-application of $\mathrm{Si}+\mathrm{EBL}$ modulated physiological processes by up-regulating enzymes associated with metabolic processes in the present study.

Increased proline and GB accumulation is the main plantresponse for maintaining tissue water potential to protect major cell metabolism and functions [92, 93]. In Cd-stressed pea seedlings, proline and GB levels increased significantly when supplemented with $\mathrm{Si}$, EBL,or both. In pea seedlings treated with both $\mathrm{Si}+\mathrm{EBL}$, proline accumulated more than GB, which was also observed in drought-stressed sorghum after Si supplementation owing to the activationof the aquaporin gene and transcription factors, thereby facilitating water uptake [94, 95]. Supplementation with 24-EBL increased proline accumulation in aluminum-stressed mung bean seedlings [96], copper-stressed mustard seedlings [86], and cold-stressed peach trees [97]. Gao and coworkers indicated that increased proline levels with EBL supplementation in peach fruit were caused by changes in the P5CS enzyme (D1-pyrroline-5-carboxylate), which activated the proline synthesis pathway, and suppressed 
proline dehydrogenase activity leading to a reduction in proline consumption. Co-application of $\mathrm{Si}+\mathrm{EBL}$ enhanced osmolyte accumulation in $\mathrm{Cd}$-stressed plants due to thelikely interactive effect on the upregulation of proline biosynthetic genes [96] and activation of transcription factors related to water relations [94].

\section{Silicon and 24-EBL reduced hydrogen peroxide MDA contents, and electrolyte leakage and methyl glyoxalase} Our data revealed a significant increase in the generation of $\mathrm{H}_{2} \mathrm{O}_{2}, \mathrm{MDA}$, and the rate of electrolyte leakage in Cd-stressed pea seedlings, relative to the control (Table 4). This may be due to Cd-induced free radical generation, which would alter membrane stability, increasing its permeability [16]. Higher ROS generation in response to $\mathrm{Cd}$ stress has been reported[1, 16-18, 92]. Enhanced production of $\mathrm{H}_{2} \mathrm{O}_{2}$ might be due to lower RWC, which would impair its distribution from generation sites [98]. In this study, supplementation with EBL and $\mathrm{Si}$, either individually or combined, reduced $\mathrm{H}_{2} \mathrm{O}_{2}$ generation. Si reduced MDA contents, $\mathrm{H}_{2} \mathrm{O}_{2}$ levels, and the electrolytic leakage rates in shoots and roots of Cd-stressed Pisum sativum [8], rice [81] and maize [73]. Application of Si reduces free radical generation by maintaining the normalized pool of osmolytes and water content within cells, as observed in $\mathrm{Cd}$-stressed peas [8]. This study confirmed that $\mathrm{Si}$ enhances the restoration of damage induced by $\mathrm{Cd}$ and improves membrane stability, as reported in Cd-stressed maize [99], cotton [79], cucumber [67], and pea [8]. Application of EBL to Cd-stressed chickpea seedlings reducedthe production of $\mathrm{H}_{2} \mathrm{O}_{2}$, lowered lipid peroxidation, and enhanced membrane stability by lowering the overall ROS generation to protect photosynthetic machinery[90]. One important reason for the reduction in lipid peroxidation and ROS production by EBL might be enhanced endogenous levels of growth hormones such as ethylene and salicylic acid that cross-talk and provide tolerance against metal stress [100]. Co-application of $\mathrm{Si}+\mathrm{EBL}$ modulated lipid peroxidation, reduced MDA content, and improved membrane stability more effectively than the individual treatments in Cd-stressed pea plants by increasing ROS scavenging activity.

\section{Silicon and 24-EBL modulated antioxidant activity}

Oxidative stress is the main response of plants to varied abiotic and biotic stresses, including heavy metal stress $[8,80,101-103]$. The antioxidant system is the key protagonist in the amelioration of oxidative stress induced by ROS $[16,104]$. We evaluated the effect of Si and EBL on the main antioxidants/antioxidant enzymes, including MDHAR, DHAR, AsA, GSH, GSSG, and GST, and enzyme activities (SOD, CAT, APX, and GR) in $\mathrm{Cd}$-stressed seedlings to determine their contribution to oxidative stress management (Table 5). Supplementation with either EBL or Si and the enhancement of Cd-induced antioxidant enzymes was thecrucialstrategy to improve seedling growth under Cdstress. Supplementation with $\mathrm{Si}$ enhanced the contents of antioxidants and antioxidant enzymes, in particular, Si significantly modulated CAT activity. Increases in CAT activity can be explained by the inhibition of $\mathrm{Cd}$ translocation from the roots to shoots in peas, which is regulated by Fe transport under Si supplementation [8]; this isbecause CAT is a heme-containing antioxidant enzyme that is dependent on the available iron pool of plants [105]. Increases in antioxidants and antioxidant enzymes in response to $\mathrm{Cd}+\mathrm{Si}$ stress has been observed in numerous plants including pakchoi[106], peanut [107], maize [99], cotton [87], wheat [23], and pea [8]. SOD and GR activities increased in response to Si application, suggesting an improved efficiency in the conversion of $\mathrm{O}_{2}-\mathrm{H}_{2} \mathrm{O}_{2}$ [25]. Si not only facilitates the activation of antioxidant enzymes but also maintains the pool of non-enzymatic antioxidants such as MDHAR, DHAR, AsA, GSH, GSSG, and GST. Wu, et al. [108] also showed that $\mathrm{Si}$-mediated increases in antioxidant enzyme activities might be an adaptive strategy to augment $\mathrm{Cd}$ stress in tomato. Increases in the antioxidant pool can be attributed to significant changes in sulfur-containing aminoacids such as cysteine and methionine in response to Si supplementation [8]. Increases in such aminoacids can be directly correlated with the higher pool of GSH in pea seedlings supplemented with $\mathrm{Si}$ [8]. Several studies have shown that Si-mediated increases in non-enzymatic antioxidants alleviate $\mathrm{Cd}$ stress in various plants such as pakchoi [106] and pea [8]. Supllementation with EBL enhanced antioxidant enzymes as well as non-enzymatic antioxidants in Cd-stressed pea plants (Table 5). Similar findings have been reported where EBL alleviated oxidative stress in Raphanus sativa [85], Brassica juncea [86], and Cicer arietinum[16] under heavy metal stress. EBL-induced enzymatic activities are attributed to the activation of genes implicated in the gene expression of SOD, APX, and CAT activities [31]. Another possible reason for the activation of enzymatic activity might be the BR signaling kinase (BSK 1), which promotes salicylic acid levels that consequently ameliorate the effects of oxidative damage [109]. Increases in GR and GST activities in response to EBL supplementation can be explained by an increment in the GSH pool and significant decline in NADPH oxidase activity, which leads to the alleviation of heavy metal-induced toxicity [84]. In addition to EBL-induced increases in the GSH pool, EBL enhances other antioxidants such as AsA, MDHAR, and DHAR, as reported in pakchoi [110], Brassica juncea [86], Ficus concinna [111], and Solanum lycopersicum [39]. Co-application of EBL+Si might up-regulate biosynthetic genes associated with the activation of enzymatic and non-enzymatic oxidants of the Asc-GSH cycle. 


\section{4-EBL maintained Gly I and Gly II activities}

One of the key strategies of plants under heavy metal stress is to accumulate MG [112-114]. In this study, higher accumulation of MG was an indicator of stress in pea seedlings (Table 6). Higher concentrations of MG lead to the depletion of GSH due to the conversion to hydroxyacylglutathione [115]. Higher levels of MG might be toxic or could result in the depletion of GSH. Supplementation of pea seedlings with $\mathrm{Si}$ and EBL individually or in combination resulted in higher accumulation of Gly I and GlyII, which protect plants against $\mathrm{Cd}$ stress-induced MG accumulation [116]. Higher MG levels were also noted in mungbean (Vigna radiata $\mathrm{L}$.) and rice (Oryza sativa L.) in response to $\mathrm{Cd}$ and $\mathrm{Cu}$ stresses, respectively, relative to the controls[19, 117]. Transgenic plants showed over-expression of GlyI and Gly II, which caused higher influx of MG levels against heavy metal stress via GSH detoxification, consequently reducing lipid peroxidation [118]. In this study, Gly I and Gly II activities increased in response to Cd stress. Similarly, enhanced Gly I activity with $\mathrm{Cd}$ and $\mathrm{Zn}$ toxicity has been reported in various plant species [112, $115,119,120]$. A decline in Gly II in response to Cd stress might be due to the proteolytic degradation of enzymes. Supplementation of EBL in Ficus concinna maintainedthe pool of Gly I and Gly II against high temperature stress [111]. Application of Si increases $\mathrm{Ca}$ uptake, which enhances Gly I and Gly II, and contributes to the decline in $\mathrm{Cd}$-induced growth inhibition $[8,20]$. Co-application of $\mathrm{Si}$ and EBL increases the uptake of minerals such as $\mathrm{Ca}$ and endogenous levels of hormones that are directly implicated in the maintenance of the glyoxalase pool and MG detoxification against Cd stress. Detoxification of MG via glyoxalase is inadequate to combat $\mathrm{Cd}$ stress and activate a tolerance strategy. Si and EBL alleviate $\mathrm{Cd}$-induced oxidative stress by maintaining Gly I and Gly II activities, indicating that both facilitate GSH restoration and glutathione redox potential via the glyoxalase system.

\section{Silicon and 24-EBL reduced $\mathrm{Cd}$ accumulation}

Due to its higher mobility in soil and plants, $\mathrm{Cd}$ is easily absorbed by plant roots (Table 6). Supplementation with $\mathrm{Si}$ reduced $\mathrm{Cd}$ accumulation in the roots, shoots, and leaves of Cd-stressed pea seedlings (Table 7), which has been reported elsewhere $[8,107]$. Si interferes with root uptake and $\mathrm{Cd}$ translocation from roots to shoots due to co-precipitation at the root surface, which decreases $\mathrm{Cd}$ transport from roots to xylem, and increases Ca uptake, thereby reducing $\mathrm{Cd}$ uptake due to competition [8]. The co-precipitation of $\mathrm{Cd}$ and $\mathrm{Si}$ in cell walls restricts $\mathrm{Cd}$ translocation from shoots to grain, which alleviates $\mathrm{Cd}$ toxicity and grain contamination. Rahman, et al. [8] revealed that $\mathrm{Si}$ supplementation coincides with an increased inflow of S-containing compounds (cysteine, methionine, and glutathione) that contribute to phytochelatin (PC) synthesis in plant tissues. Phytochelatin can function as a second-line defense against $\mathrm{Cd}$ stress. Moreover, Si forms silicates within the cytoplasm, leading to the inhibition of symplastic transport of heavy metals $[121,122]$. Si application can improve Cd toxicity by increasing plant tolerance to Cd stress. EBL reduced $\mathrm{Cd}$ accumulation in roots, shoots, and leaves of pea seedlings (Table 5). Supplementation with EBL reduced $\mathrm{Cd}$ accumulation by increasing $\mathrm{Ca}$ absorption and maintaining ionic homeostasis [43, 91]. Further, 24-EBL enhances the uptake of $\mathrm{K}^{+}, \mathrm{Ca}^{2+}$, and $\mathrm{Mg}^{2+}$ in the roots, and these cations are preferentially transported to younger leaves through vascular tissues to reduce $\mathrm{Cd}$ translocation [17]. Moreover, 24-EBL enhances the absorption of essential inorganic ions, reducesthe uptake of toxic ions, and promotes ion homeostasis, especially $\mathrm{K}^{+} / \mathrm{Na}^{+}, \mathrm{Ca}^{2+}$, and $\mathrm{Mg}^{2+}$ in the upper leaves, $\mathrm{Ca}^{2}$ ${ }^{+} \mathrm{Na}^{+}$and $\mathrm{Mg}^{2+} / \mathrm{Na}^{+}$in the roots, and $\mathrm{K}^{+} / \mathrm{Na}^{+}$in the petioles $[2,123]$. Hence, the co-application of $\mathrm{Si}+\mathrm{EBL}$ reduced $\mathrm{Cd}$ accumulation by maintaining ion homeostasis, offering better conditions for osmotic adjustment, and blocked Cd uptake by co-precipitation.

\section{Silicon and 24-EBL enhanced mineral uptake}

Mineral nutrition is crucial for plant growth and development. Our study showed that cadmium impairs mineral uptake in pea seedlings (macro, Table 8; micro, Table 9), more so in shoots than roots. Cadmium impairs mineral absorption in other species including beans [41, 124], tomato [125], and Arabidopsis thaliana [126]. In this study, Si supplementation significantly increased macro- and micronutrient levels in the shoots and roots of control and Cd-stressed pea seedlings. Si supplementation maintains phosphorus homeostasis by regulating the uptake and overload of phosphorus from soil [127], and improves potassium uptake by activating H-ATPase even at low concentrations [127, 128]. Abdel Latef and Tran [129] have shown increased nitrogen and calcium uptake in crops after supplementation with sodium metasilicate. Si increases the oxidizing power of roots, thereby preventing surplus uptake of iron and limiting iron toxicity [130]. Further, Si regulates iron uptake from acidic soils via the release of $\mathrm{OH}$ through plant roots when plantsare supplemented with Si [110]. Supplementation with $\mathrm{Si}$ influences the solubility of various elements such as $\mathrm{P}, \mathrm{K}$, and $\mathrm{Ca}$ and hinders the uptake of toxic metals such as $\mathrm{Cd}$, As, and $\mathrm{Cu}$ in rice grains [131]. Si supplementation alters phosphorus precipitation along with Fe and Mn in potato plants [132]. Tripathi, et al. [133] found that $\mathrm{Si}$ enhanced macro- $(\mathrm{Mg}, \mathrm{Ca}$, and $\mathrm{K})$ and micronutrients ( $\mathrm{Zn}$ and $\mathrm{Fe}$ ) in rice seedlings under chromium stress. Supplementation with EBL increased both 
macro- and micronutrient uptake in Cd-stressed and control pea plants. In cucumber seedlings, EBL application improves nitrogen metabolism by maintaining ion homeostasis through the excessive flow of $\mathrm{Ca}^{2+}$ and $\mathrm{Mg}^{2+}$ into shoots and roots [134]. EBL increases Fe uptake by enhancing ferric chelate reductase activity, thereby enhancing Fe (III) reduction to Fe (II) and consequently increasing Fe content in cucumber seedlings [135]. Foliar application of EBL increased $\mathrm{H}^{+}$-ATPase activity resulting in a surplus of Fe in plants. Application of EBL activates both $\mathrm{H}^{+}$-ATPase and $\mathrm{Ca}^{2+}$-ATPase in roots and leaves of Fe-deficient pea plants [136]. $\mathrm{H}^{+}$-ATPase can establish an electrochemical potential gradient to maintain ion balance in plants [137], and $\mathrm{Ca}^{2+}$ functions as an intracellular messenger in coupling an extensive range of extracellular signals to explicit responses [138], thus enhancing ion uptake and translocation. Co-application of EBL+ Si augmented mineral nutrition by decreasing the uptake of toxic metals and increasing cation exchange capacity.

\section{Conclusion}

$\mathrm{Cd}$ stress induces numerous physiological and biochemical processes that inhibit plant growth and metabolism. These toxic effects were ameliorated in Cd-stressed pea seedlings by supplementation with Si or EBL, or a combination of the two, which was more effective. The potential mechanism for the favorable effects of $\mathrm{Si}$ and EBR are summarized as follows: (1) restoration of chlorophyll and physiological activities such as photosynthetic efficiency, stomatal conductance, $\mathrm{CO}_{2}$ assimilation rate, stomatal conductance, and transpiration rate;(2) decline in $\mathrm{Cd}$ root-to-shoot translocation; (3) increasein antioxidant enzyme activity and generation of antioxidant molecules such as AsA and GSH; (4) higher accumulation of osmolytes such as proline and GB; (5) improved mineral uptake resulting in higher physiological activity; and (6) detoxification of MG via the glyoxalase system. The results of our study indicate that co-application of $\mathrm{Si}+\mathrm{EBL}$ is an eco-friendly way for improving the performance of plants under $\mathrm{Cd}$ stress. Further studies are needed to elucidate the mechanism underlying the interactive effect of $\mathrm{Si}$ + EBL in Cd detoxification. These findings might provide further potential for the relevance of Si and EBL in phytoremediation and $\mathrm{Cd}$ detoxification in crops.

\section{Acknowledgements}

The authors would like to extend their sincere appreciation to the Deanship of Scientific Research at King Saud University for its funding (Research group No. RGP-199).

\section{Funding}

Research group, RGP-199.

\section{Authors' contributions}

SJ, MNA and PAhmad designed and performed the experiments. SJ and PAhmad write the manuscript. LW and DE conducted the statistical analysis. PAlam wrote the discussion part of this manuscript. KBS helped in writing and refining the manuscript. All authors read and approved the final manuscript.

Ethics approval and consent to participate

Not applicable.

\section{Consent for publication}

Not applicable

Competing interests

The authors declare that no conflict of interest exists.

\section{Publisher's Note}

Springer Nature remains neutral with regard to jurisdictional claims in published maps and institutional affiliations.

\section{Author details}

${ }^{1}$ ICAR- Central Institute of Temperate Horticulture, Rangreth, Air Field, Srinagar, Jammu, Kashmir, India. ${ }^{2}$ Department of Botany and Microbiology, Faculty of Science, King Saud University, Riyadh 11451, Saudi Arabia. ${ }^{3}$ Biology Department, College of Science and Humanities, Prince Sattam bin Abdulaziz University, Alkharj, Kingdom of Saudi Arabia. ${ }^{4}$ The UWA Institute of Agriculture and School of Agriculture \& Environment, The University of Western Australia, LB 5005, Perth, WA 6001, Australia. ${ }^{5}$ Department of Botany, S.P. College, Srinagar, Jammu, Kashmir 190001, India.

Received: 21 November 2017 Accepted: 2 July 2018

Published online: 16 July 2018

\section{References}

1. Ahmad P, Abd Allah EF, Hashem A, Sarwat M, Gucel S. Exogenous application of selenium mitigates cadmium toxicity in Brassica juncea $\mathrm{L}$. (Czern \& Cross) by up-regulating antioxidative system and secondary metabolites. J Plant Growth Regul. 2016;35:936-50.

2. Ahmad $P$, Ahanger MA, Egamberdieva D, Alam P, Alyemeni MN, Ashraf M. Modification of osmolytes and antioxidant enzymes by 24-epibrassinolide in chickpea Seedlings under mercury (Hg) toxicity. J Plant Growth Regul. 2018; 37:309-22.

3. Yousaf B, Amina LG, Wang R, Imtiaz M, Rizwan MS, Zia-ur-Rehman M, Qadir A, Si Y. The importance of evaluating metal exposure and predicting human health risks in urban-periurban environments influenced by emerging industry. Chemosphere. 2016:150:79-89.

4. Jan S, Parray JA. Approaches to heavy metal tolerance in plants. New Delhi, India: Springer; 2016.

5. Chaney RL. How Does contamination of rice soils with $\mathrm{Cd}$ and $\mathrm{Zn}$ cause high incidence of human $\mathrm{Cd}$ disease in subsistence rice farmers. Curr Pollut Rep. 2015;1:13-22.

6. Rizwan M, Ali S, Abbas T, Zia-ur-Rehman M, Hannan F, Keller C, Al-Wabel MI, Ok YS. Cadmium minimization in wheat: A critical review. Ecotoxicol Environ Saf. 2016;130:43-53.

7. O'Mara K, Cresswell T. Trophic variations in uptake and assimilation of cadmium, manganese and zinc: An estuarine food-chain radiotracer experiment. World Academy of Science, Engineering and Technology. Intern J Environ Ecol Engineer. 2018;5(1).

8. Rahman MF, Ghosal A, Alam MF, Kabir AH. Remediation of cadmium toxicity in field peas ( Pisum sativum L.) through exogenous silicon. Ecotoxicol Environ Saf. 2017;135:165-72.

9. He S, Yang X, He Z, Baligar VC. Morphological and physiological responses of plants to cadmium toxicity: A review. Pedosphere. 2017;27:421-38.

10. Baldantoni D, Morra L, Zaccardelli M, Alfani A. Cadmium accumulation in leaves of leafy vegetables. Ecotoxicol Environ Saf. 2016;123:89-94.

11. Kumar V, Sah SK, Khare T, Shriram V, Wani SH. Engineering phytohormones for abiotic stress tolerance in crop plants. In: Ahammed GJ, Yu JQ editors. Plant hormones under challenging environmental factors. Springer Netherlands; 2016. p. 247-66.

12. Mombo S, Foucault Y, Deola F, Gaillard I, Goix S, Shahid M, Schreck E, Pierart A, Dumat C. Management of human health risk in the context of kitchen 
gardens polluted by lead and cadmium near a lead recycling company. J Soils Sediment. 2015;16:1214-24.

13. Jin C, Nan Z, Wang H, Li X, Zhou J, Yao X. Jin P :Effect of Cd stress on the bioavailability of $\mathrm{Cd}$ and other mineral nutrition elements in broad bean grown in a loess subsoil amended with municipal sludge compost. Environ Sci Poll Res. 2018;25(8):7418-32.

14. Mitra S, Pramanik K, Sarkar A, Ghosh PK, Soren T, Maiti TK. Bioaccumulation of cadmium by Enterobacter sp. and enhancement of rice seedling growth under cadmium stress. Ecotox Environ Saf. 2018;156:183-96.

15. Finger-Teixeira A, MdL LF, Ricardo Soares A, da Silva D, Ferrarese-Filho O. Cadmium-induced lignification restricts soybean root growth. Ecotoxicol Environ Saf. 2010;73:1959-64.

16. Ahmad P, Abdel Latef AA, Abd_Allah EF, Hashem A, Sarwat M, Anjum NA, Gucel S. Calcium and potassium supplementation enhanced growth, osmolyte secondary metabolite production, and enzymatic antioxidant machinery in cadmium-exposed chickpea (Cicer arietinum L.). Frontiers Plant Sci. 2016;7:513.

17. Ahmad P, Ahanger MA, Alyemeni MN, Wijaya L, Alam P. Exogenous application of nitric oxide modulates osmolyte metabolism, antioxidants, enzymes of ascorbate-glutathione cycle and promotes growth under cadmium stress in tomato. Protoplasma. 2018;255(1):79-93.

18. Ahmad P, Alyemeni MN, Wijaya L, Alam P, Ahanger MA, Alamri SA. Jasmonic acid alleviates negative impacts of cadmium stress by modifying osmolytes and antioxidants in faba bean (Vicia faba L.). Arch Agron Soil Sci. 2017;63:1889-99.

19. Nahar K, Hasanuzzaman M, Alam MM, Rahman A, Suzuki T, Fujita M. Polyamine and nitric oxide crosstalk: Antagonistic effects on cadmium toxicity in mung bean plants through upregulating the metal detoxification, antioxidant defense and methylglyoxal detoxification systems. Ecotoxicol Environ Saf. 2016;126:245-55.

20. Hasanuzzaman M, Nahar K, Rahman A, Mahmud JA, Hossain S, Alam K, Oku $H$, Fujita M. Actions of biological trace elements in plant abiotic stress tolerance. In: Naeem M, Ansari AA, GIII SS editors. Essential plant nutrients: Uptake, use efficiency, and management. Switzerland AG: Springer Nature; 2017. p. 213-74.

21. Ahmad P, Ahanger MA, Egamberdieva D, Alam P, Alyemeni MN, Ashraf M. Modification of osmolytes and antioxidant enzymes by 24-epibrassinolide in chickpea seedlings under mercury (Hg) toxicity. J Plant Growth Regul. 2018; 37(1):309-22.

22. Manquián-Cerda K, Cruces E, Escudey M, Zúriiga G, Calderon R. Interactive effects of aluminum and cadmium on phenolic compounds, antioxidant enzyme activity and oxidative stress in blueberry (Vaccinium corymbosum L.) plantlets cultivated in vitro. Ecotoxicol Environ Saf. 2018;150:320-6.

23. Hasanuzzaman M, Hossain MA, Fujita M. Nitric oxide modulates antioxidant defense and the methylglyoxal detoxification system and reduces salinityinduced damage of wheat seedlings. Plant Biotechnol Rep. 2011;5:353-65.

24. Tang J, Han Z, Chai J. Q\&A: what are brassinosteroids and how do they act in plants? BMC Biol. 2016;14:113.

25. Wang Q, Zhang L, Zou J, Liu D, Yue J. Effects of cadmium on root growth, cell division and micronuclei formation in root tip cells of Allium cepa var. agrogarum L. ФYTON. 2014;83:291-8.

26. Sun H, Dai H, Wang X, Wang G. Physiological and proteomic analysis of selenium-mediated tolerance to Cd stress in cucumber (Cucumis sativus L.). Ecotoxicol Environ Saf. 2016;133:114-26.

27. Ahmad P, Abdel Latef AA, Hashem A, Abd_Allah EF, Gucel S, Tran L-SP. Nitric oxide mitigates salt stress by regulating levels of osmolytes and antioxidant enzymes in chickpea. Front Plant Sci. 2016;7:347.

28. Sirhindi G, Mir MA, Abd-Allah EF, Ahmad P, Gucel S. Jasmonic acid modulates the physio-biochemical attributes, antioxidant enzyme activity, and gene expression in Glycine max under nickel toxicity. Frontiers in Plant Science. 2016;7:591.

29. Sharma P, Kumar A, Bhardwaj R. Plant steroidal hormone epibrassinolide regulate - Heavy metal stress tolerance in Oryza sativa L. by modulating antioxidant defense expression. Environ Exp Bot. 2016;122:1-9.

30. Kohli SK, Handa N, Gautam V, Bali S, Sharma A, Khanna K, Arora S, Thukral AK, Ohri $P$, Karpets $Y$, et al. ROS signaling in plants under heavy metal stress. In: Khan MIR, Khan NA, editors. Reactive oxygen species and antioxidant systems in plants: Role and regulation under abiotic stress. Singapore: Springer; 2017. p. 185-214.

31. Kohli SK, Handa N, Sharma A, Gautam V, Arora S, Bhardwaj R, Alyemeni MN, Wijaya L, Ahmad P. Combined effect of 24-epibrassinolide and salicylic acid mitigates lead $(\mathrm{Pb})$ toxicity by modulating various metabolites in Brassica juncea L. seedlings. Protoplasma. 2018;255(1):11-24.

32. Kaur R, Yadav P, Thukral AK, Sharma A, Bhardwaj R, Alyemeni MN, Wijaya L, Ahmad P. Castasterone and Citric Acid Supplementation Alleviates Cadmium Toxicity by Modifying Antioxidants and Organic Acids in Brassica juncea. J Plant Growth Regul. 2018;37:286-99.

33. Balakhnina TI, Matichenkov W, Wlodarczyk T, Borkowska A, Nosalewicz M, Fomina IR. Effects of silicon on growth processes and adaptive potential of barley plants under optimal soil watering and flooding. Plant Growth Regulation. 2012;67:35-43.

34. Farooq MA, Dietz K-J. Silicon as versatile player in plant and human biology: Overlooked and poorly understood. Frontiers in Plant Science. 2015;6.

35. Bhatt D, Sharma G. Role of silicon in counteracting abiotic and biotic plant stresses. IJCS. 2018;6(2):1434-42.

36. Cooper JW, Hu Y, Beyyoudh L, Yildiz Dasgan H, Kunert K, Beveridge CA, Foyer $\mathrm{CH}$. Strigolactones positively regulate chilling tolerance in pea and in Arabidopsis. Plant, cell \& Environ. 2018;41(6):1298-310.

37. Ahmad F, Singh A, Kamal A. Crosstalk of brassinosteroids with other phytohormones under various abiotic stresses. J Appl Biology \& Biotech. 2018;6(1):56-62.

38. Shahzad B, Tanveer M, Che Z, Rehman A, Cheema SA, Sharma A, Zhaorong D. Role of 24-epibrassinolide (EBL) in mediating heavy metal and pesticide induced oxidative stress in plants: A review. Ecotox Environ Saf. 2018;147: 935-44.

39. Soares C, de Sousa A, Pinto A, Azenha M, Teixeira J, Azevedo RA, Fidalgo F. Effect of 24-epibrassinolide on ROS content, antioxidant system, lipid peroxidation and Ni uptake in Solanum nigrum L. under Ni stress. Environ Exp Bot. 2016;122:115-25.

40. Hayat S, Hasan SA, Yusuf M, Hayat Q, Ahmad A. Effect of 28-homobrassinolide on photosynthesis, fluorescence and antioxidant system in the presence or absence of salinity and temperature in Vigna radiata. Environ Exp Bot. 2010;69: 105-12.

41. Santos LR, Batista BL, Lobato AKS. Brassinosteroids mitigate cadmium toxicity in cowpea plants. Photosynthetica. 2018;56(2):591-605.

42. Bukhari SAH, Wang R, Wang W, Ahmed IM, Zheng W, Cao F. Genotypedependent effect of exogenous 24-epibrassinolide on chromium-induced changes inultrastructure and physicochemical traits in tobacco seedlings. Environ Sci Pollut Res. 2016;23:18229-38.

43. Dong Y, W-f C, Bai X, Liu F, Wan Y. Effects of Exogenous Nitric Oxide and 24-Epibrassinolide on Physiological Characteristics of Peanut under Cadmium Stress. Pedosphere. 2018. https://doi.org/10.1016/S10020160(17)60376-X.

44. Clemens S, Aarts MGM, Thomine S, Verbruggen N. Plant science: the key to preventing slow cadmium poisoning. Trend Plant Sci. 2013;18:92-9.

45. Hoagland DR, Arnon DI. The water culture method for growing plants without soil. California Agricultural Experimental Station, University of California, Berkeley. Circular. 1950;347:1-32.

46. Hiscox JD, Israelstam GF. A method for the extraction of chlorophyll from leaf tissue without maceration. Can J Bot. 1979;57:1332-4.

47. Lichtenthaler HK, Wellburn AR. Determinations of total carotenoids and chlorophyllsaandbof leaf extracts in different solvents. Biochem Soc Trans. 1983;11:591-2.

48. Genty B, Harbinson J, Briantais J-M, Baker NR. The relationship between non-photochemical quenching of chlorophyll fluorescence and the rate of photosystem 2 photochemistry in leaves. Photosynthesis Res. 1990;25:249-57.

49. Velikova V, Yordanov I, Edreva A. Oxidative stress and some antioxidant systems in acid rain-treated bean plants. Plant Sci. 2000;151:59-66.

50. Madhava Rao KV, Sresty TVS. Antioxidative parameters in the seedlings of pigeonpea (Cajanus cajan (L.) Millspaugh) in response to $\mathrm{Zn}$ and Ni stresses. Plant Sci. 2000;157:113-28.

51. Dionisio-Sese ML, Tobita S. Antioxidant responses of rice seedlings to salinity stress. Plant Sci. 1998;135:1-9.

52. Wild R, Ooi L, Srikanth V, Münch G. A quick, convenient and economical method for the reliable determination of methylglyoxal in millimolar concentrations: the $\mathrm{N}$-acetyl-I-cysteine assay. Anal Bioanal Chem. 2012;403:2577-81.

53. Yamasaki S, Dillenburg LR. Measurements of leaf relative water content in Araucaria angustifolia. Revista Brasilleira de fisiologia vegetal. 1999;11:69-75.

54. Bates LS, Waldren RP, Teare ID. Rapid determination of free proline for water-stress studies. Plant Soil. 1973;39:205-7.

55. Grieve CM, Grattan SR. Rapid assay for determination of water soluble quaternary ammonium compounds. Plant Soil. 1983;70:303-7. 
56. Beyer WF, Fridovich I. Assaying for superoxide dismutase activity: Some large consequences of minor changes in conditions. Anal Biochem. 1987; 161:559-66.

57. Nakano Y, Asada K. Hydrogen peroxide is scavenged by ascorbate-specific peroxidase in spinach chloroplasts. Plant Cell Physiol. 1981;22:867-80.

58. Aebi H. Catalase in vitro. Method Enzymol 105:121-6.

59. Foyer $\mathrm{CH}$, Halliwell B. The presence of glutathione and glutathione reductase in chloroplasts: A proposed role in ascorbic acid metabolism. Planta. 1976;133:21-5.

60. Hasanuzzaman M, Fujita M. Exogenous sodium nitroprusside alleviates arsenic-induced oxidative stress in wheat (Triticum aestivum L.) seedlings by enhancing antioxidant defense and glyoxalase system. Ecotoxicology. 2013; 22:584-96.

61. Miyake C, Asada K. Thylakoid-bound sscorbate peroxidase in spinach chloroplasts and photoreduction of its primary oxidation product monodehydroascorbate radicals in thylakoids. Plant Cell Physiol. 1992;33:541-53.

62. Principato GB, Rosi G, Talesa V, Giovannini E, Norton SJ. A comparative study on glyoxalase II from vertebrata. Enzyme. 1987;37:164-8.

63. Huang C, He W, Guo J, Chang X, Su P, Zhang L. Increased sensitivity to salt stress in an ascorbate-deficient Arabidopsis mutant. J Exp Bot. 2005:56:3041-9.

64. Yu C-W, Murphy TM, Lin C-H. Hydrogen peroxide-induced chilling tolerance in mung beans mediated through ABA-independent glutathione accumulation. Funct Plant Biol. 2003;30:955.

65. Rasool S, Urwat U, Nazir M, Zargar SM, Zargar MY. Cross talk between phytohormone signaling pathways under abiotic stress conditions and their metabolic engineering for conferring abiotic stress tolerance. In: Zargar SM, Zargar MY editors. Abiotic Stress-Mediated Sensing and Signaling in Plants: An Omics Perspective. Springer; 2018. p. 329-50.

66. Ullah H, Luc PD, Gautam A, Datta A. Growth, yield and silicon uptake of rice (Oryza sativa) as influenced by dose and timing of silicon application under water-deficit stress. Arch Agron Soil Sci. 2017;64:1-13.

67. Bu R, Xiao X, Liao W, Hu Y, Li J, Lv J, Xie J. Exogenous Si alleviation of autotoxicity in Cucumber (Cucumis sativus L.) seed germination is correlated with changes in carbohydrate metabolism. J Plant Growth Regul. 2018. https://doi.org/10.1007/s00344-017-9773-8.

68. Shi Z, Yang S, Han D, Zhou Z, Li X, Liu Y, Zhang B. Silicon alleviates cadmium toxicity in wheat seedlings (Triticum aestivum L.) by reducing cadmium ion uptake and enhancing antioxidative capacity. Environ Sci Poll Res. 2018;25(8):7638-46.

69. Farooq MA, Ali S, Hameed A, Bharwana SA, Rizwan M, Ishaque W, Farid M, Mahmood K, lqbal Z. Cadmium stress in cotton seedlings: Physiological, photosynthesis and oxidative damages alleviated by glycinebetaine. S Afr J Bot. 2016;104:61-8.

70. Li Y, Song Y, Shi G, Wang J, Hou X. Response of antioxidant activity to excess copper in two cultivars of Brassica campestris ssp. chinensis Makino. Acta Physiol Plant. 2008;31:155-62.

71. Saeidnejad A, Mardani H, Naghibolghora M. Protective effects of salicylic acid on physiological parameters and antioxidants response in maize seedlings under salinity stress. J Appl Environ Biol Sci. 2012;2:364-73.

72. Wu J, Geilfus CM, Pitann B, Mühling KH. Silicon-enhanced oxalate exudation contributes to alleviation of cadmium toxicity in wheat. Environ Exper Bot. 2016;131:10-8.

73. Srivastava RK, Pandey P, Rajpoot R, Rani A, Gautam A, Dubey RS. Exogenous application of calcium and silica alleviates cadmium toxicity by suppressing oxidative damage in rice seedlings. Protoplasma. 2014;252:959-75.

74. Muradoglu F, Gundogdu M, Ercisli S, Encu T, Balta F, Jaafar H, Zia-Ul-Haq M. Cadmium toxicity affects chlorophyll $a$ and $b$ content, antioxidant enzyme activities and mineral nutrient accumulation in strawberry. Biol Res. 2015;48:11.

75. Paunov M, Koleva L, Vassilev A, Vangronsveld J, Goltsev V. Effects of different metals on photosynthesis: Cadmium and zinc affect chlorophyll fluorescence in Durum Wheat. Intern. J Mol. Sci. 2018;19(3):787.

76. da Silva AJ, do Nascimento CWA, da Silva Gouveia-Neto A, da Silva-Jr EA. LED-induced chlorophyll fluorescence spectral analysis for the early detection and monitoring of cadmium toxicity in maize plants. Water Air Soil Pollut. 2012:223:3527-33.

77. Vaculík M, Pavlovič A, Lux A. Silicon alleviates cadmium toxicity by enhanced photosynthetic rate and modified bundle sheath's cell chloroplasts ultrastructure in maize. Ecotoxicol Environ Saf. 2015;120:66-73.

78. Wu Q, Su N, Chen Q, Shen W, Shen Z, Xia Y, Cui J. Cadmium-induced hydrogen accumulation is involved in cadmium tolerance in Brassica campestris by reestablishment of reduced glutathione homeostasis. Plos One. 2015;10:e0139956.
79. Bharwana SA, Ali S, Farooq MA, lqbal N, Abbas F and Ahmad MSA. Alleviation of lead toxicity by silicon is related to elevated photosynthesis, antioxidant enzymes suppressed lead uptake and oxidative stress in cotton. J Bioremed Biodeg. 2013;4:187.

80. Adrees M, Ali S, Rizwan M, Zia-ur-Rehman M, Ibrahim M, Abbas F, Farid M, Qayyum MF, Irshad MK. Mechanisms of silicon-mediated alleviation of heavy metal toxicity in plants: A review. Ecotoxicol Environ Saf. 2015;119:186-97.

81. Liu J, Ma J, He C, Li X, Zhang W, Xu F, Lin Y, Wang L. Inhibition of cadmium ion uptake in rice (Oryza sativa) cells by a wall-bound form of silicon. New Phytol. 2013;200:691-9.

82. Wu H, Wang J, Ou Y, Li B, Jiang W, Liu D, Zou J. Cadmium uptake and localization in roots of Salix matsudana Koidz. Fres Environ Bullet. 2015; 24(12A):4504-11.

83. Ramakrishna B, Rao SSR. Foliar application of brassinosteroids alleviates adverse effects of zinc toxicity in radish (Raphanus sativus L.) plants. Protoplasma. 2014;252:665-77.

84. Kanwar MK, Bhardwaj R, Chowdhary SP, Arora P, Sharma P, Kumar S. Isolation and characterization of 24-Epibrassinolide from Brassica juncea $\mathrm{L}$. and its effects on growth, $\mathrm{Ni}$ ion uptake, antioxidant defense of Brassica plants and in vitro cytotoxicity. Acta Physiol Plant. 2012;35:1351-62.

85. Choudhary SP, Kanwar M, Bhardwaj R, Yu J-Q, Tran L-SP. Chromium stress mitigation by polyamine-brassinosteroid application involves phytohormonal and physiological strategies in Raphanus sativus L. PLoS One. 2012;7:e33210

86. Siddiqui $\mathrm{H}$, Hayat S, Bajguz A. Regulation of photosynthesis by brassinosteroids in plants. Acta Physiol Plant. 2018;40(3):59.

87. Farooq MA, Ali S, Hameed A, Ishaque W, Mahmood K, Iqbal Z. Alleviation of cadmium toxicity by silicon is related to elevated photosynthesis, antioxidant enzymes; suppressed cadmium uptake and oxidative stress in cotton. Ecotoxicol Environ Saf. 2013:96:242-9.

88. Ali S, Farooq MA, Yasmeen T, Hussain S, Arif MS, Abbas F, Bharwana SA, Zhang $\mathrm{G}$. The influence of silicon on barley growth, photosynthesis and ultra-structure under chromium stress. Ecotoxicol Environ Saf. 2013;89:66-72.

89. Tripathi DK, Singh VP, Prasad SM, Chauhan DK, Kishore Dubey N, Rai AK. Silicon-mediated alleviation of $\mathrm{Cr}(\mathrm{VI})$ toxicity in wheat seedlings as evidenced by chlorophyll florescence, laser induced breakdown spectroscopy and anatomical changes. Ecotoxicol Environ Saf. 2015;113:133-44.

90. Hayat S, Hasan SA, Ahmad A. Growth, nitrate reductase activity and antioxidant system in cadmium stressed tomato (Lycopersicon esculentum Mill.) cultivars/Croissance, activité de la nitrate réductase et du système antioxydant chez les cultivars de tomate (Lycopersicon esculentum Mill.) soumis à un stress au cadmium. Biotechnologie, Agronomie, Société et Environnement. 2011;15:401.

91. Wani AS, Tahir I, Ahmad SS, Dar RA, Nisar S. Efficacy of 24-epibrassinolide in improving the nitrogen metabolism and antioxidant system in chickpea cultivars under cadmium and/or NaCl stress. Sci Horticul. 2017;225:48-55.

92. Ahmad P, Sarwat M, Bhat NA, Wani MR, Kazi AG, Tran L-SP. Alleviation of cadmium toxicity in Brassica juncea L. (Czern. \& Coss.) by calcium application involves various physiological and biochemical strategies. Plos One. 2015;10:e0114571.

93. Ahanger MA, Agarwal RM, Tomar NS, Shrivastava M. Potassium induces positive changes in nitrogen metabolism and antioxidant system of oat (Avena sativa L cultivar Kent). J Plant Interact. 2015;10:211-23.

94. Liu J, Gao H, Wang X, Zheng Q, Wang C, Wang X, Wang Q. Effects of 24-epibrassinolide on plant growth, osmotic regulation and ion homeostasis of salt-stressed canola. Plant Biol. 2013;16:440-50.

95. Khattab HI, Emam MA, Emam MM, Helal NM, Mohamed MR. Effect of selenium and silicon on transcription factors NAC5 and DREB2A involved in drought-responsive gene expression in rice. Biol Plant. 2014;58:265-73.

96. Ali B, Hasan SA, Hayat S, Hayat Q, Yadav S, Fariduddin Q, Ahmad A. A role for brassinosteroids in the amelioration of aluminium stress through antioxidant system in mung bean (Vigna radiata L. Wilczek). Environ Exp Bot. 2008;62:153-9.

97. Gao H, Zhang Z, Lv X, Cheng N, Peng B, Cao W. Effect of 24-epibrassinolide on chilling injury of peach fruit in relation to phenolic and proline metabolisms. Postharvest Biol Technol. 2016;111:390-7.

98. Weisany W, Sohrabi Y, Heidari G, Siosemardeh A, Ghassemi-Golezani K. Physiological responses of soybean ('Glycine max'L.) To zinc application under salinity stress. Aust J Crop Sci. 2011;5:1441.

99. Lukačová Z, Švubová R, Kohanová J, Lux A. Silicon mitigates the Cd toxicity in maize in relation to cadmium translocation, cell distribution, antioxidant 
enzymes stimulation and enhanced endodermal apoplasmic barrier development. Plant Growth Regul. 2013;70:89-103.

100. Fariduddin Q, Yusuf M, Ahmad I, Ahmad A. Brassinosteroids and their role in response of plants to abiotic stresses. Biol Plant. 2013;58:9-17.

101. Ali S, Bharwana SA, Rizwan M, Farid M, Kanwal S, Ali Q, Ibrahim M, Gill RA, Khan MD. Fulvic acid mediates chromium $(\mathrm{Cr}$ ) tolerance in wheat (Triticum aestivum L.) through lowering of $\mathrm{Cr}$ uptake and improved antioxidant defense system. Environ Sci Pollut Res. 2015;22:10601-9.

102. Ali S, Chaudhary A, Rizwan M, Anwar HT, Adrees M, Farid M, Irshad MK, Hayat T, Anjum SA. Alleviation of chromium toxicity by glycinebetaine is related to elevated antioxidant enzymes and suppressed chromium uptake and oxidative stress in wheat (Triticum aestivum L.). Environ Sci Pollut Res. 2015;22:10669-78

103. Jan S, Parray JA. Approaches to heavy metal tolerance in plants. Singapore: Springer Singapore; 2016.

104. Schieber M, Chandel Navdeep S. ROS Function in Redox Signaling and Oxidative Stress. Curr Biol. 2014;24:R453-62.

105. Jan S, Parween T, Siddiqi TO, Mahmooduzzafar. Anti-oxidant modulation in response to gamma radiation induced oxidative stress in developing seedlings of Psoralea corylifolia L. J Environ Radioact. 2012;113:142-9.

106. Song A, Li Z, Zhang J, Xue G, Fan F, Liang Y. Silicon-enhanced resistance to cadmium toxicity in Brassica chinensis L. is attributed to Si-suppressed cadmium uptake and transport and Si-enhanced antioxidant defense capacity. J Hazard Mater. 2009;172:74-83.

107. Shi G, Cai Q, Liu C, Wu L. Silicon alleviates cadmium toxicity in peanut plants in relation to cadmium distribution and stimulation of antioxidative enzymes. Plant Growth Regul. 2010;61:45-52.

108. Wu J, Guo J, Hu Y, Gong H. Distinct physiological responses of tomato and cucumber plants in silicon-mediated alleviation of cadmium stress. Front Plant Sci. 2015;6:453

109. Deng X-G, Zhu T, Peng X-J, Xi D-H, Guo H, Yin Y, Zhang D-W, Lin H-H. Role of brassinosteroid signaling in modulating tobacco mosaic virus resistance in Nicotiana benthamiana. Sci Rep. 2016;6:20579.

110. Wang $X$, Shi $Y$, Chen $X$, Huang B. Screening of Cd-safe genotypes of Chinese cabbage in field condition and $\mathrm{Cd}$ accumulation in relation to organic acids in two typical genotypes under long-term Cd stress. Environ Sci Pollut Res. 2015;22:16590-9.

111. Jin SH, Li XQ, Wang GG, Zhu XT: Brassinosteroids alleviate high-temperature injury in Ficus concinna seedlings via maintaining higher antioxidant defence and glyoxalase systems. AoB Plants. 2015;7:plv009-plv009.

112. Hossain MA, Hossain MZ, Fujita M. Stress-induced changes of methylglyoxal level and glyoxalase I activity in pumpkin seedlings and cDNA cloning of glyoxalase I gene. Aust J Crop Sci. 2009;3:53.

113. Devanathan S, Erban A, Perez-Torres R, Kopka J, Makaroff CA. Arabidopsis thaliana glyoxalase 2-1 is required during abiotic stress but is not essential under normal plant growth. Plos One. 2014;9:e95971.

114. Hoque TS, Hossain MA, Mostofa MG, Burritt DJ, Fujita M, Tran L-SP. Methylglyoxal: An emerging signaling molecule in plant abiotic stress responses and tolerance. Front Plant Sci. 2016:7:1341.

115. Kalapos MP, Garzó T, Antoni F, Mandl J. Accumulation of S-dlactoylglutathione and transient decrease of glutathione level caused by methylglyoxal load in isolated hepatocytes. Biochim Biophys Acta. 1992; 1135:159-64.

116. Hossain MA, Fujita M. Purification of glyoxalase I from onion bulbs and molecular cloning of its cDNA. Biosci Biotechnol Biochem. 2009;73:2007-13.

117. Mostofa MG, Saegusa D, Fujita M, Tran L-SP. Hydrogen sulfide regulates salt tolerance in rice by maintaining $\mathrm{Na}^{+} / \mathrm{K}^{+}$balance, mineral homeostasis and oxidative metabolism under excessive salt stress. Front Plant Sci. 2015;6:1055.

118. Upadhyaya CP, Venkatesh J, Gururani MA, Asnin L, Sharma K, Ajappala H, Park SW. Transgenic potato overproducing l-ascorbic acid resisted an increase in methylglyoxal under salinity stress via maintaining higher reduced glutathione level and glyoxalase enzyme activity. Biotechnol Lett. 2011;33:2297-307.

119. Hossain MA, Hasanuzzaman M, Fujita M. Up-regulation of antioxidant and glyoxalase systems by exogenous glycinebetaine and proline in mung bean confer tolerance to cadmium stress. Physiol Mol Biol Plants. 2010;16:259-72.

120. Lin F, Xu J, Shi J, Li H, Li B. Molecular cloning and characterization of a novel glyoxalase I gene TaGly I in wheat (Triticum aestivum L.). Mol Biol Rep. 2009;37:729-35.
121. Cao Z, Yue Y, Zhong H, Qiu P, Chen P, Wen X, Wang S, Liu G. The cationic dye removal by novel SiZn composites prepared from zinc ash. J Taiwan Institute Chem Engineer. 2017;71:464-73.

122. Ji X, Liu S, Juan $H$, Bocharnikova EA, Matichenkov W. Effect of silicon fertilizers on cadmium in rice (Oryza sativa) tissue at tillering stage. Environ Sci Pollu Res. 2017:24:10740-8

123. Waisi H, Petkovic A, Nikolic B, Jankovic B, Raicevic V, Lalevic B, Giba Z. Influence of 24-epibrassinolide on seedling growth and distribution of mineral elements in two maize hybrids. Chem Indus. 2017;71:201-9.

124. Wael MS, Mostafa MR, Taia AAE-M, Saad MH, Magdi TA. Alleviation of cadmium toxicity in common bean (Phaseolus vulgaris L.) plants by the exogenous application of salicylic acid. J Horticul Sci Biotechnol. 2015;90: 83-91.

125. Hassan Z, Aarts MGM. Opportunities and feasibilities for biotechnological improvement of $\mathrm{Zn}$, Cd or Ni tolerance and accumulation in plants. Environ Exp Bot. 2011;72:53-63.

126. Yamaguchi C, Takimoto Y, Ohkama-Ohtsu N, Hokura A, Shinano T, Nakamura T, Suyama A, Maruyama-Nakashita A. Effects of cadmium treatment on the uptake and translocation of sulfate in Arabidopsis thaliana. Plant Cell Physiol. 2016;57:2353-66.

127. Xu CX, Ma YP, Liu YL. Effects of silicon (Si) on growth, quality and ionic homeostasis of aloe under salt stress. S Afr J Bot. 2015:98:26-36.

128. Yin L, Wang S, Tanaka K, Fujihara S, Itai A, Den X, Zhang S. Silicon-mediated changes in polyamines participate in silicon-induced salt tolerance in Sorghum bicolor L. Plant Cell Environ. 2015;39:245-58.

129. Abdel Latef AA, Tran L-SP. Impacts of priming with silicon on the growth and tolerance of maize plants to alkaline stress. Front Plant Sci. 2016;7:243.

130. Ma JF, Takahashi E. Silicon in soil. In: Book Silicon in soil: Elsevier; 2002. p. $27-48$

131. Malav JK, Patel K, Sajid M. Influence of silicon fertilization on yield and nutrients uptake (Si, P, K, S \& Na) of rice (Oryza sativa L.). The. Ecoscan. 2015; 9:629-34.

132. Pilon C, Soratto RP, Moreno LA. Effects of soil and foliar application of soluble silicon on mineral nutrition, gas exchange, and growth of potato plants. Crop Sci. 2013:53:1605.

133. Tripathi DK, Singh VP, Kumar D, Chauhan DK. Impact of exogenous silicon addition on chromium uptake, growth, mineral elements, oxidative stress, antioxidant capacity, and leaf and root structures in rice seedlings exposed to hexavalent chromium. Acta Physiol Plant. 2011;34:279-89.

134. Yuan L, Shu S, Sun J, Guo S, Tezuka T. Effects of 24-epibrassinolide on the photosynthetic characteristics, antioxidant system, and chloroplast ultrastructure in Cucumis sativus L. under $\mathrm{Ca}\left(\mathrm{NO}_{3}\right)_{2}$ stress. Photosynthesis Res. 2012;112:205-14.

135. Wang B, Li Y, Zhang W-H. Brassinosteroids are involved in response of cucumber (Cucumis sativus) to iron deficiency. Ann Bot. 2012;110:681-8.

136. Song $Y L$, Dong YJ, Tian XY, Kong J, Bai XY, Xu LL, He ZL. Role of foliar application of 24-epibrassinolide in response of peanut seedlings to iron deficiency. Biol Plant. 2016:60:329-42.

137. Palmgren MG. PLANT PLASMA MEMBRANE H+-ATPases: Powerhouses for nutrient uptake. Annu Rev Plant Physiol Plant Mol Biol. 2001:52:817-45.

138. Zhang C: Integration Of Extracellular And Intracellular Signals Via The Calcium Sensing Receptor (CASR). 2014.

\section{Ready to submit your research? Choose BMC and benefit from:}

- fast, convenient online submission

- thorough peer review by experienced researchers in your field

- rapid publication on acceptance

- support for research data, including large and complex data types

- gold Open Access which fosters wider collaboration and increased citations

- maximum visibility for your research: over $100 \mathrm{M}$ website views per year

At BMC, research is always in progress.

Learn more biomedcentral.com/submissions 